\title{
Using Some Natural Substrates to Enhance the Growth, Yield and the Tolerance of Strawberry Plants to Rhizoctonia Root Rot Disease
}

\author{
S. M. Rizk ${ }^{1}$ and Maha H. Mohamed ${ }^{2}$ \\ ${ }^{1}$ Potato and Vegetatively Propagated Vegetables Res. Dept., Hort. Inst., Agric. Res. Centre, Giza, Egypt. \\ ${ }^{2}$ Plant Pathology Dept., Fac. Agric., Ain Shams Univ., Cairo, Egypt
}

Received on: 21-9-2021

Accepted on: 15-11-2021

\begin{abstract}
The experiments were carried out during 2019/2020 and 2020/2021 seasons. Greenhouse experiments carried out at Department of Plant pathology, Faculty of Agriculture, Ain Shams University. While, the field experiments were carried out at El-Kanater Research Station, Qaluobia Governorate, to study the effect of some natural compounds (chitosan, methionine, and ascorbic acid) on the tolerance of strawberry plants to Rhizoctonia root rot disease, as well as the vegetative growth, chemical composition of the plant, fruit yield and its components, as well as the quality of the yield of strawberry Festival Cultivar compared to untreated infected strawberry plants.

Obtained results showed that applications with chitosan at $500 \mathrm{ppm}$, methionine at $20 \mathrm{ppm}$ and ascorbic acid at 20 $\mathrm{mM}$ via transplant root soaking, foliar spray, and combining the root soaking with foliar spray, or transplant root soaking with Rhizolex $(1 \mathrm{~g} / \mathrm{L})$ showed significant decrease in root rot incidence caused by Rhizoctonia solani. The combining of root soaking with foliar spray of chitosan or methionine resulted the highest significant decreases of disease incidence under greenhouse and field conditions. However, all applications except Rhizolex resulted in significant increases in phenolic compounds, oxidative enzymes activity i.e., PPO, SOD and CAT in roots during the two growing seasons.

Obtained results showed also that soaking plus foliar spraying with chitosan at 500ppm, methionine at $20 \mathrm{ppm}$ and ascorbic acid at $20 \mathrm{mM}$ significantly increased all vegetative growth characters, N, P, K and total carbohydrates in plant foliage, fruit yield and its components as well as physical and chemical fruit quality.
\end{abstract}

KEYWORDS: Strawberry, Rhizoctonia solani, Chitosan, Methionine, Ascorbic acid, Antioxidant enzymes, Growth, Yield.

\section{INTRODUCTION}

Strawberry (Fragaria $X$ anannasa Duch.) is one of the most important vegetable crops in Egypt for fresh consumption, processing and exportation. Strawberry plant is affected by many soil borne fungi causing root rot disease. Rhizoctonia spp. are among them that causing sever root rot symptoms. The disease cause a deterioration of the main root system, declines the vigor and productivity of the plant causing reduction in the yield (Awad 2016; Errifi et al., 2019).

Several new natural substrates have an activity on the plant diseases control. Such materials also play an important role in improving plant growth characteristics and crop productivity.

Chitosan and its derivatives have been studied as an antimicrobial against a wide range of microorganisms including bacteria and fungi (Liman et al., 2011). However, several studies have proved the preventing effectiveness of chitosan against fungal growth by directly interfering or by activating certain vitality processes (El Ghaouth et al., 1992a and b).
Chitosan is also known to be eliciting the plant defense responses by activating pathogenesis-related gene functions such as chitosanase, chitinase and $\beta$ glucanase (Mauch et al., 1984; Benhamou and Theriault, 1992; Notsu et al., 1994).

Numerous studies have reported the ability of chitosan to increase plant growth (height, leaf number, fresh and dry weight), yield components (fruit number/plant, fruit weight and total yield) and plant contents of $\mathrm{N}, \mathrm{P}$ and $\mathrm{K}$ in different plant species cultivated under diverse growth conditions on strawberry El-Miniawy et al. (2013), Shams et al. (2014), Nithin et al. (2020) and Nithin et al. (2020).

Shafshak et al. (2011), Manal et al., (2019) and Fatma and Hanaa (2020) found that amino acids increased vegetative growth and chemical constituents of strawberry plant foliage. However, L-Methionine is a precursor of ethylene and growth factors such as spermine and spermidine (Singh, 1999). It also has a role in the revitalization of rooting.

Previous studies revealed that amino acids play an effective role in inducing plant systemic 


\section{S. M. Rizk and Maha H. Mohamed., 2021}

resistance against fungal plant diseases (Kadotani et al., 2016). Foliar spray with different concentrations $(0,5,10,25$, and $50 \mathrm{mM})$ of L-arginine, Lmethionine, L-ornithine decreased the severity of canker disease caused by Xanthomonas citri subsp. citri as a result of induction of plant resistance due to increases of $\beta$-1,3-glucanase and activity of antioxidant enzymes, catalase, peroxidase, and phenylalanine ammonia-lyase (Hasabi et al., 2014). Also, potato tuber slice treatment with L-methionine significantly decreased dry rot caused by Fusarium solani (Mohamed and Mostafa, 2021).

Ascorbic acid (vitamin C) is an essential antioxidant in the ascorbate-glutathione pathway in plant. It is a cofactor for many enzymes, including those involved in cell wall synthesis, most notably in the hydroxylation of proline residues (Smith et al., 2007; Abo-Hinna and Merza, 2012). Moreover, Gad El-Hak et al. (2012) reported that foliar spraying of ascorbic acid improved vegetative growth and yield as well as pod soluble solid substances and pigments constituents of leaves and pods of pea plants. Also, Anany and Ismail (2020) on common bean found that, foliar spray of vitamin $\mathrm{C}$ significantly increase growth and total yield and leaf contents of nutritional values. Also, ascorbic acid is considered the first line of plant defense against damaging reactive oxygen species (ROS), that protecting plant cells from any factors that induce oxidative stress, such as salinity, wounding (Boubakri, 2017), and plant pathogens attacks (SomaiJemmali et al., 2015 ; Boubakri, 2017). Foliar application of pepper with ascorbic acid, chitosan and saccharin significantly reduced of powdery and downy mildew comparing with fungicide treated plants (Abdel-Kader and El-Mougy, 2014).

The aim of the current study was to investigate the effect of chitosan, methionine and ascorbic acid by different application methods (soaking the transplant roots, foliar spraying and soaking plus foliar spraying) on root rot disease caused by Rhizoctonia solani, vegetative growth, yield, and quality characteristics of strawberry fruits.

\section{MATERIAL AND METHODS}

\subsection{Isolation and identification of the pathogen}

Samples of strawberry plants exhibit symptoms of Rhizoctonia root rot disease were collected from Al Qalyubia Governorate fields. The isolation of the casual fungi was carried out as usual. For purification Rhizoctonia-like mycelia, hyphal-tip of developed mycelium growth were picked up then sub-cultured on Petri dishes contained PDA media.
Plates were incubated as above for 5 days until isolates grow well. Identification of isolates was carried out according to Parmeter and Whitney (1970).

\subsection{Fungal inoculum preparation}

Sand was washed with a hydrochloric acid and dried then distribution in $9 \mathrm{~cm}$ diameter Petri dishes (120 g/dish). Sandy dishes were wetted by pouring Czapek Dox broth $(25 \mathrm{ml} /$ plate $)$ then autoclaved at $121^{\circ} \mathrm{C}$ for $30 \mathrm{~min}$. After cooling, sandy dishes were infected by putting pieces of actively fungal growth. The plates were incubated at $25 \pm 1^{\circ} \mathrm{C}$ for 7 days. Sandy dishes containing the fungal growth were used for infestation of pots. To infestation the pots, two dishes were used for every earthen pot $(20 \mathrm{~cm}$ diameter, each pot contains approximately $3000 \mathrm{~g}$ sandy loam soil). Infected pots were left for 7 days with daily irrigation follow-up before transplanting (Mohamed et al., 2015).

\subsection{Pathogenicity tests}

Three isolates were obtained of genus Rhizoctonia solani. The isolates were tested for their pathogenicity on strawberry (Festival cv.) in greenhouse. Soil infestation was performed 7 days before transplanted as described above. One transplant was transferred in earthen pots $(20 \mathrm{~cm}$ in diameter) containing infected or non-infected (control) sterilized sandy loam soil $(1: 1)$ with 18 replicates for each isolate. Pots were kept under greenhouse conditions. Pots were irrigated daily with water, and every 7 days by NPK fertilizer. Data were recorded as percentage of disease incidence and disease severity of infected root areas to determine the virulence of tested isolates.

\subsection{Effect of some natural substrates on} Rhizoctonia root rot disease, total phenols, oxidative enzymes and parameters of strawberry plant growth

All experiments were conducted during two successive seasons of 2019/2020 and 2020/2021. Greenhouse experiments were carried out at Department of Plant Pathology, Faculty of Agriculture, Ain Shams University. Field experiments were carried out at the experimental farm at ElKanater Horticulture Research Station (El-Qaluobia Governorate), Agricultural Research Center (ARC), Egypt.

Tested substrates including chitosan at 500 ppm, methionine at $20 \mathrm{ppm}$ and ascorbic acid at 20 $\mathrm{mM}$ were applied by different methods as: soaking the roots of transplants before planting for 15 minutes in 


\section{Scientific Journal of Agricultural Sciences 3 (2): 40-0, 2021}

substrate, foliar spray, combined treatments of root soaking and foliar spraying as well as, soaking the roots of transplants before planting for 15 minutes in the Rhizolex at $1 \mathrm{~g} / \mathrm{L}$ and untreated plants as control. Foliar spray treatments were started after 25 days from transplanting and every 15 days for 5 times through the growing season. All experiments were arranged in a randomized complete blocks design in three replicates.
In greenhouse experiments, the isolate of Rhizoctonia solani that appeared highest degree of infection in pathogenicity test was used for artificial soil infestation as described above. Seedlings were cultivated and all treatments were applied as mentioned above with 18 replicates for each treatment.

In field experimental the soil was sandy loam in texture with $\mathrm{PH}$ of 7.28 Soil mechanical and chemical analyses are shown in Table (1).

Table 1. The chemical properties of pot sand soil

\begin{tabular}{|c|c|c|c|c|c|}
\hline \multicolumn{2}{|c|}{ Physical analysis } & \multicolumn{4}{|c|}{ Chemical analysis } \\
\hline \multirow[b]{2}{*}{$\begin{array}{l}\text { Sp \% } \\
\text { Coarse sand } \\
\text { Fine sand } \\
\text { Silt } \\
\text { Clay }\end{array}$} & \multirow[b]{2}{*}{$\begin{array}{l}58.00 \% \\
9.56 \% \\
17.93 \% \\
33.84 \% \\
38.67 \%\end{array}$} & \multicolumn{2}{|c|}{ Cations meq/l } & \multicolumn{2}{|c|}{ Anions meq/l } \\
\hline & & $\begin{array}{l}\mathrm{Ca}^{+2} \\
\mathrm{Mg}^{+2} \\
\mathrm{Na}+ \\
\mathrm{K}+\end{array}$ & $\begin{array}{l}5.27 \\
2.38 \\
3.78 \\
0.17\end{array}$ & $\begin{array}{l}\mathrm{CO}_{3} \\
\mathrm{HCO}_{3} \\
\mathrm{Cl}^{-} \\
\mathrm{SO}_{4}^{-2}\end{array}$ & $\begin{array}{l}0 \\
2.17 \\
3.46 \\
5.97\end{array}$ \\
\hline $\begin{array}{l}\text { Soil pH } \\
\text { E.C, dS/m }\end{array}$ & $\begin{array}{l}7.28 \\
1.18\end{array}$ & $\begin{array}{l}\text { Available N } \\
\text { Available P } \\
\text { Available K }\end{array}$ & $\begin{array}{l}22.5 \\
16.21 \\
209 \mathrm{n}\end{array}$ & & \\
\hline
\end{tabular}

The area of the experimental plot was 12.25 $\mathrm{m}^{2}$ included one bed each seven meters in length and 1.75 meters in width. Each bed included four rows and the transplanting was done at $25 \mathrm{~cm}$ apart between transplants in the same row. Transplanting was done on 1 and 3 of October in 2019/2020 and 2020/2021, respectively. Sprinkler irrigation was used in the first month after transplanting, after that, the beds were covered with 40 micron black plastic mulch. After planting the drip irrigation was used after mulching until the end of the growing season.

Random samples of three plants of strawberry root from each greenhouse experimental were uprooted after $72 \mathrm{hr}$ of transplanting to determine phenolic compounds and antioxidant defensive enzymes activities.

\subsubsection{Disease assessment}

Disease incidence was determined 20 days after transplanting on 18 and 147 plants in greenhouse and field experiments, respectively. In greenhouse, plants were uprooted after130 days from transplanting to determined disease severity of Rhizoctonia root rot by using scale (0 to 5) according to Fang et al. (2013).

\subsubsection{Determination of total soluble phenols}

Total soluble phenols in strawberry roots (grown under greenhouse conditions) were determined using the method described by Shahidi and Naczk (1995). The concentration of total soluble phenols was calculated using the standard curve of catechol. Total soluble phenols concentration was expressed as $\mu \mathrm{g}$ equivalents of catechol per $\mathrm{g} \mathrm{FW}$ of the sample.

\subsubsection{Enzymes assay}

For enzyme extraction frozen tissues (one gram) of root (grown under greenhouse conditions) were ground and homogenized with $4 \mathrm{ml}$ cold sodium phosphate buffer $(100 \mathrm{mM}, \mathrm{pH}=7)$ containing $1 \%$ (w/v) polyvinylpyrrolidone (PVP) and $0.1 \mathrm{mM}$ EDTA by using cold mortar and pestle. The homogenate was centrifuged at $10000 \mathrm{rpm}$, at $4^{\circ} \mathrm{C}$ for $15 \mathrm{~min}$. The supernatant was used for determination the activity of polyphenol oxidase (PPO), superoxide dismutase (SOD) and catalase (CAT). The activity of PPO was measured based on the method described by Oktay et al. (1995). The activity of SOD was according to Beyer and Fridovich (1987). The activity assay of CAT was determined according to Sumner and Somers (1947). All the enzymes activity was expressed as unit. $\mathrm{mg}^{-1}$ protein. Protein concentration was determined in the crude extract according to Bradford (1976) by using bovine serum albumin as a standard curve. 
S. M. Rizk and Maha H. Mohamed., 2021
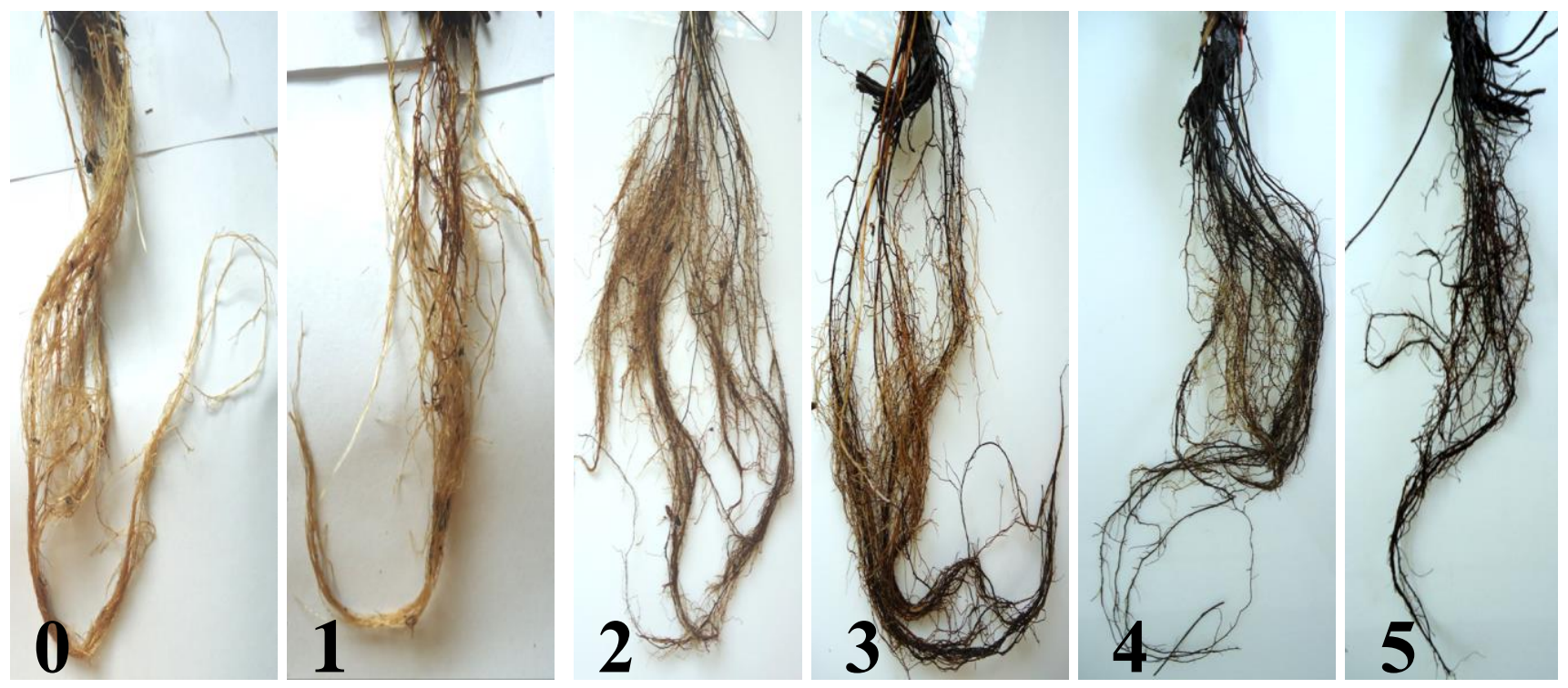

Fig 1. The degree of rot severity on strawberry roots using scoring from 0 to 5 according to (Fang $e t$ al., 2013) as follows $0=$ healthy root, no discoloration; $1:<25 \%$ root discolored; $2: \geq 25 \%<$ $50 \%$ root discolored; $3: \geq 50 \%<75 \%$ root discolored; 4: $\geq 75 \%$ root discolored; 5: all root rotted.

\subsubsection{Vegetative growth characteristics}

Three plants (in greenhouse experiments) and five plants (in field experiments) were taken from each experimental unit after 130 days from planting to determine plant height $(\mathrm{cm})$, fresh and dry weight/plant shoots $(\mathrm{g})$, number of leaves/plant, crown diameter $(\mathrm{cm})$, root fresh and dry weight $(\mathrm{g})$.

In field experiments, chemical composition of plant foliage, i.e., total carbohydrates, nitrogen, phosphorus and potassium were determined according to A. O. A. C. (1990), Pregl (1945), John (1970) and Brown and Lilleland (1946), respectively.

\subsubsection{Fruit yield and its components}

Early fruit yield was determined as weight of all harvested fruits at the ripe stage during December and January. Exportable yield was calculated as weight of harvested fruits at the 3/4 color stage during December and January after discarding the misshaped fruits. Also, total fruit yield per plant and feddan. Marketable yield was calculated after discarding the infected fruits. Un-marketable yield was calculated as weight of infected fruits during the harvesting season.

\subsubsection{Physical and chemical fruit quality}

A random samples of 10 fruits at marketable stage from each experimental plot was taken to determine the following properties. Average fruit weight, fruit length, fruit diameter and fruit firmness. Total soluble solids (T.S.S.), total titratable acidity, ascorbic acid and anthocyanin as the method described in A. O. A.C. (1990). Total sugars were determined as the method described by Nelson (1974).

\subsection{Statistical analysis}

All obtained data were analyzed by analysis of variance (ANOVA). Least significant differences at $p=0.05$ and Duncan's multiple range test was applied to compare between means (Gomez and Gomez, 1984).

\section{RESULTS AND DISCUSSION}

\subsection{The pathogen and pathogenicity test}

Three isolates of Rhizoctonia spp. (RS1, RS2 and RS3) were isolated from strawberry root showed typical symptoms of Rhizoctonia root rot disease. Identification of the isolates ensured that all of them have identical specifications of $R$. solani. Isolate RS1 showed the highest percentage of disease incidence and disease severity Figs (2and3). 


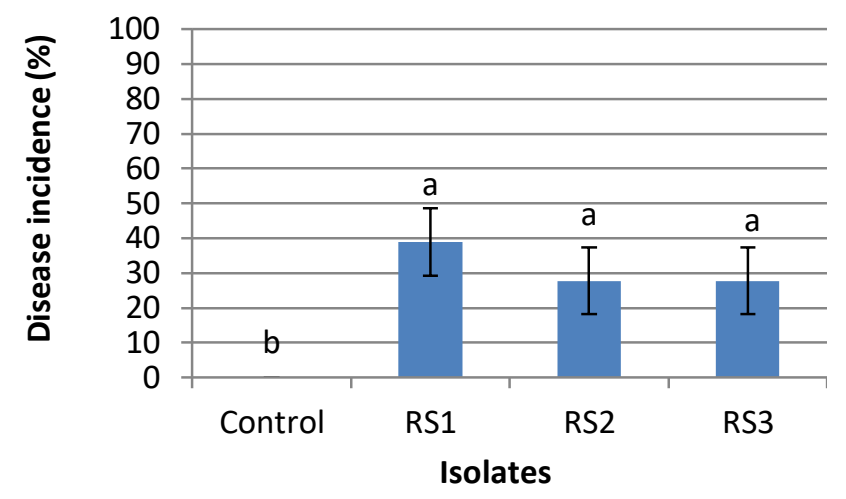

Fig 2. Root rot incidence on strawberry by Rhizoctonia isolates under greenhouse conditions.

3.2. Effect of some natural substrates on Rhizoctonia root rot disease, total phenols, oxidative enzymes, and parameters of strawberry plant growth

Effect of natural substrates or Rhizolex on the incidence and severity of root rot under greenhouse conditions were illustrated in Figs. (4,5,6 and7) and on the incidence in field experiments were shown in Figs. (8and9). Data in Fig. (4) clarify that all treatments resulted in clear significant decrease in disease incidence except foliar spray with ascorbic acid compared with control. Meanwhile, the foliar spray plus seedling root soaking in all substrates (chitosan,

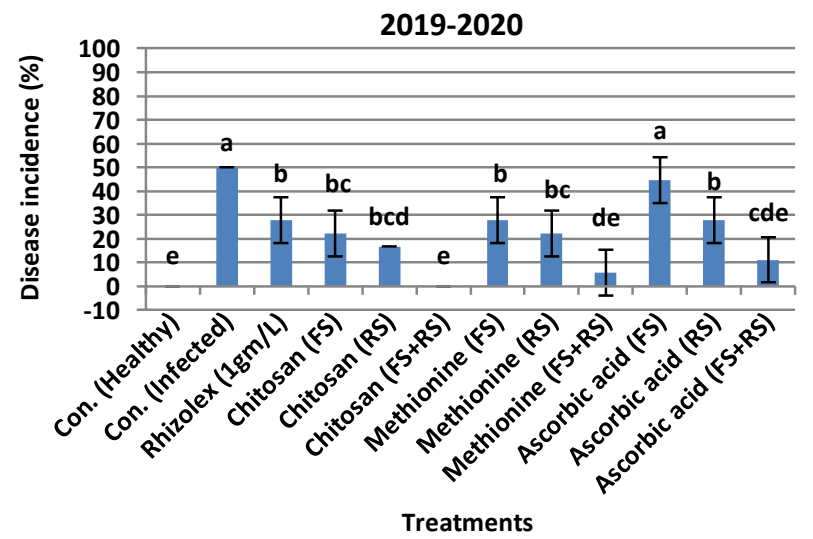

Fig 4. Effect of some natural substrates on the incidence of root rot disease on strawberry under greenhouse conditions during 2019/2020

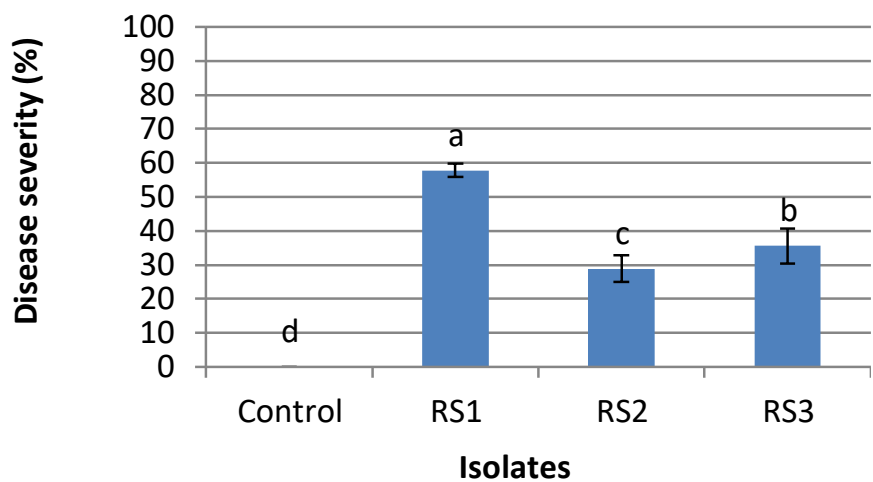

Fig 3. Disease severity of Rhizoctonia isolates on strawberry root under greenhouse conditions.

methionine and ascorbic acid) recorded the highest reduction in the percentage of plants death than control or than other treatments. Data in Fig. (5) showed that all treatments resulted in clear significant decrease in disease severity. The foliar spray plus seedling root soaking of chitosan and methionine gave the highest values of reduction in disease severity, followed by the foliar spray with chitosan. In addition, the results of both incidence and severity of root rot disease tended in similar trend in the second season (Figs 6 and7). Also, the similar results of the disease incidence in field experiments were recorded (Fig. 8).

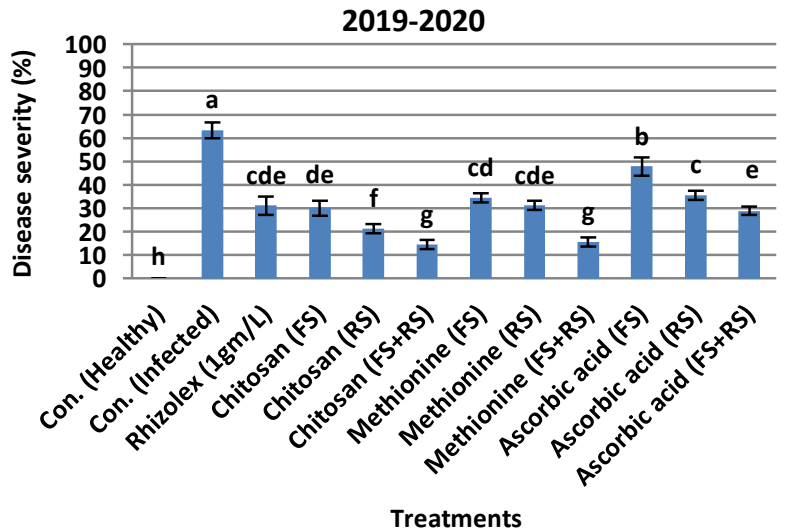

Fig 5. Effect of some natural substrates on the severity of root rot diseases on strawberry under greenhouse conditions during 2019/2020. 


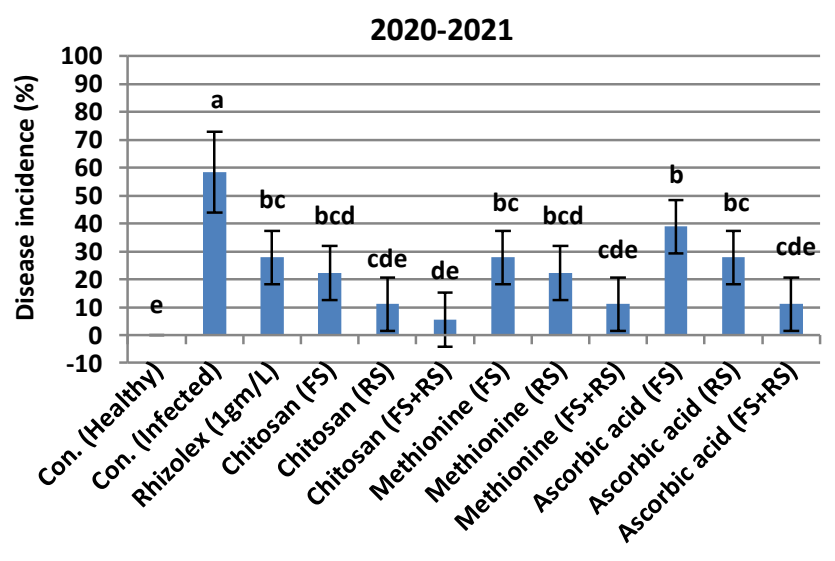

Treatments

Fig 6. Effect of some natural substrates on the incidence of root rot disease on strawberry under greenhouse conditions during 2020/2021.

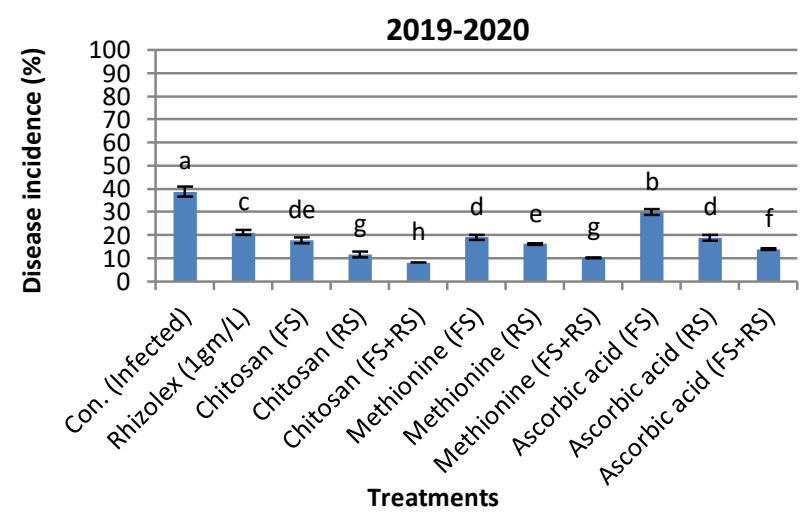

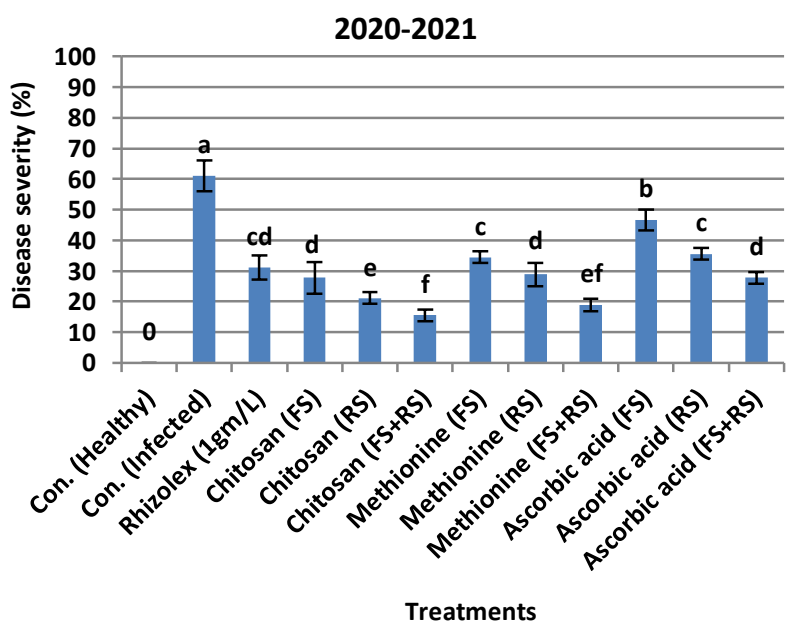

Fig 7. Effect of some natural substrates on the severity of root rot diseases on strawberry under greenhouse conditions during 2020/2021.
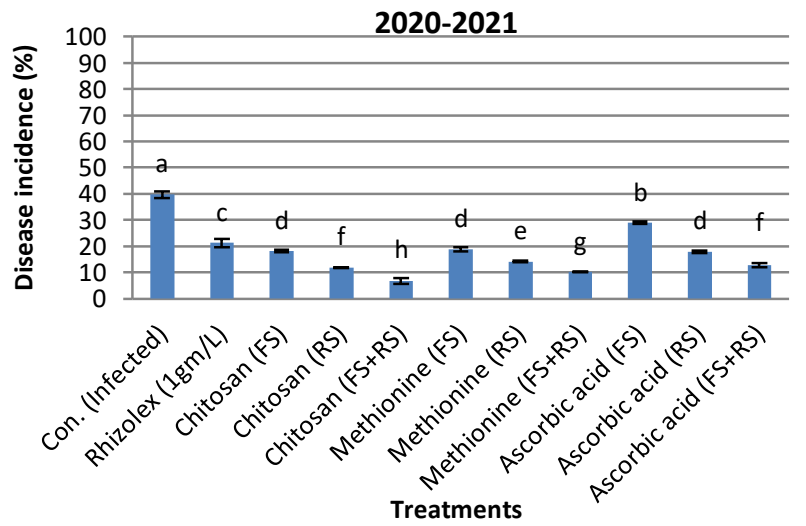

Fig 8. Effect of some natural substrates on the incidence of root rot disease on strawberry under field conditions during seasons 2019/2020- 2020/2021.

\subsubsection{Total phenolic compounds}

Data in Fig. (9) indicated that the level of total phenolic compounds was significantly increased in all applications with chitosan, methionine and ascorbic acid compared with untreated infected plants. no significant effect was found in root application with Rhizolex compared with control or other applications in both seasons. In the first season, foliar spray plus transplant root soaking of chitosan and methionine recorded the highest phenolic compounds 780.4 and $779.4 \mu \mathrm{g} / \mathrm{g} \mathrm{FW}$, respectively followed by foliar spray plus transplant root soaking of ascorbic acid 684.4 $\mu \mathrm{g} / \mathrm{g}$ FW compared to untreated infected plants 320.5 $\mu \mathrm{g} / \mathrm{g} \mathrm{FW}$. Also, the same trend in the second season, data showed that the maximum level of phenols was detected in application with foliar spray plus transplant root soaking of chitosan and methionine were obtained 516.0 and $512.8 \mu \mathrm{g} / \mathrm{g}$ FW, respectively followed by seedling root soaking of methionine was recorded $494.2 \mu \mathrm{g} / \mathrm{g} \mathrm{FW}$ compared to untreated infected plants $239.2 \mu \mathrm{g} / \mathrm{g}$ FW. Phenols are considered the components of lignin which increase the plant cell wall resistance against cell wall degrading enzymes (Bhuiyan et al., 2009). It can be conclude that chitosan, methionine, and ascorbic acid can induce strawberry resistance response to $R$. solani by increasing the concentrations of phenolic compounds, which restrict or weaken pathogen growth throw forming around wounds or pathogen infected areas (Reimers and Leach, 1991). 

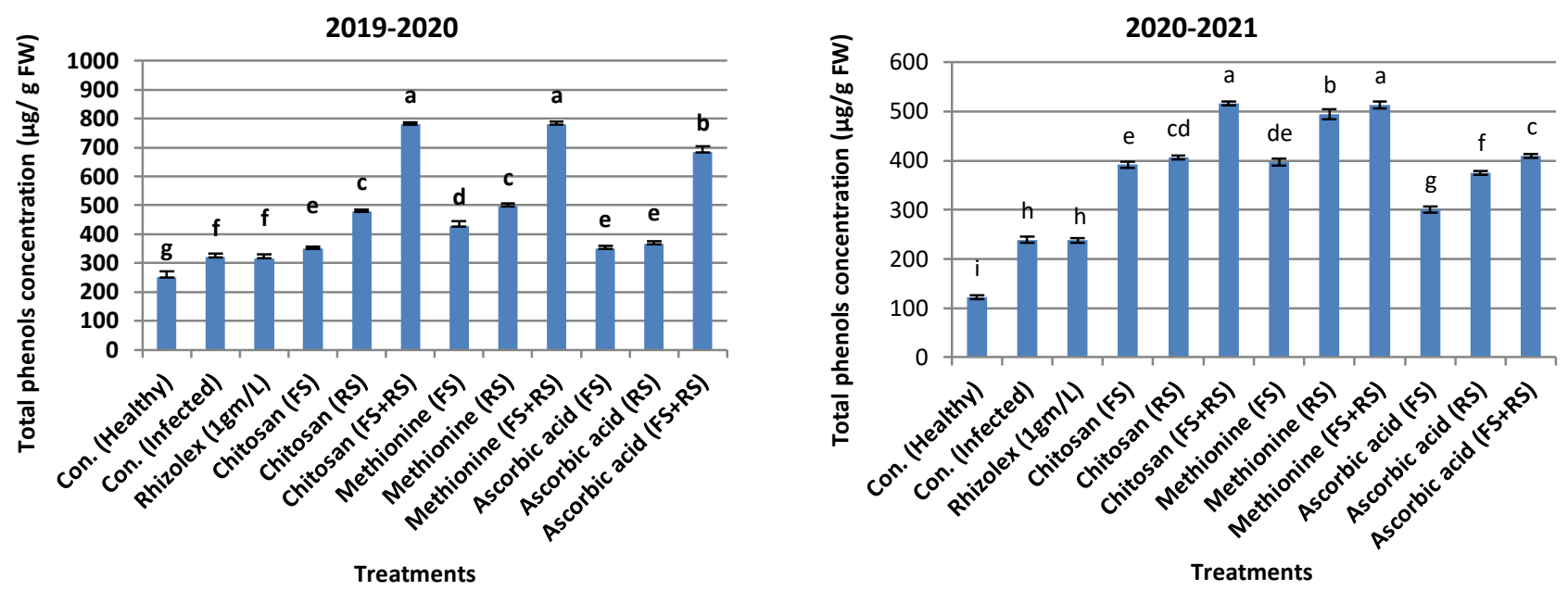

Fig 9. Effect of some natural substrates on phenolic compounds in infected strawberry with Rhizoctonia solani during two seasons 2019/2020 and 2020/2021.

\subsubsection{Antioxidant defensive enzymes}

Data presented in Fig. (10) showed that all applications with chitosan, methionine and ascorbic acid led to significant increase in polyphenol oxidase (PPO) activity compared with untreated plants in both seasons. Application with the foliar spray plus transplant root soaking of chitosan followed by the same application with methionine attained the highest PPO activity in strawberry root compared with untreated control. On the otherwise, all applications with ascorbic acid recorded least PPO activity. Otherwise, there were no significant differences in PPO activity between root application with Rhizolex and untreated infected plants in first season. However, in second season compared with control, Rhizolex application led to decrease in PPO activity.

The activity of superoxide dismutase (SOD) was significantly affected by all applications of chitosan, methionine and ascorbic acid. Application with the foliar spray plus seedling root soaking of chitosan attained the highest SOD activity in strawberry root followed by the same application with methionine compared with untreated control. Otherwise, root application with Rhizolex decreased SOD activity compared with untreated infected plants in both seasons (Fig. 11).

The enzyme activities of catalase (CAT) were significantly increased in all applications with chitosan, methionine and ascorbic acid compared to untreated control as shown in Fig. (12) in two successive seasons. However, in the first season, the maximum increase in CAT activity was resulted with the foliar spray plus seedling root soaking of chitosan followed by transplant root soaking with chitosan compared to untreated infected plants. Furthermore, in the second season, the maximum increase in CAT activity was resulted with the foliar spray plus transplant root soaking of chitosan followed by the same application with methionine compared with untreated infected plants. On the other hand, there were no significant differences in CAT activities between root application with Rhizolex and untreated infected plants in both seasons.

Increasing the activities of three antioxidant enzymes i.e., PPO, SOD and CAT ensured the role of theses substrates (chitosan, methionine and ascorbic acid) in induction of strawberry resistance against $R$. solani. These findings agree with a numerous studies on the role of these enzymes in plant resistance (Oliveira et al., 2016). Also, these results are in agreement with previous findings that chitosan was reported to induce resistance against several soil borne fungi (Ashley et al., 1998; Benhamou and Theriault, 1992; Abd-El-Kareem et al., 2002). In this regard, soil amended with chitin and chitosan resulted significant reduction of disease incidence and disease severity of Fusarium yellows disease of celery (Ashley et al., 1998). Otherwise, the reduction of strawberry Rhizoctonia root rot disease with chitin treatments may have been due to the direct effect on Rhizoctonia solani via chitin decomposition releases volatiles such as ammonia which suppress several soil borne fungi (Sneh and Henis, 1972; Bell et al., 1998; Stamford et al., 2010; Kim et al., 2016). In present study, the observed reduction in strawberry root rot incidence or severity may be attributed to indirect effect of chitin and its defense response in plants. In this respect, several studies reported that various plants treatment with chitosan induced plant resistance by increasing antioxidant enzymes activities (Matta et al., 1988; Siddaiah et al., 2018). 
S. M. Rizk and Maha H. Mohamed., 2021

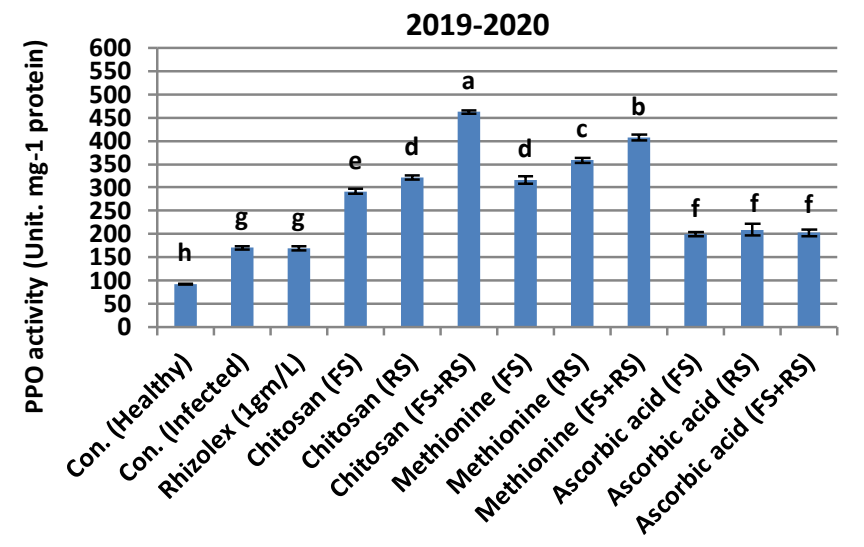

Treatments

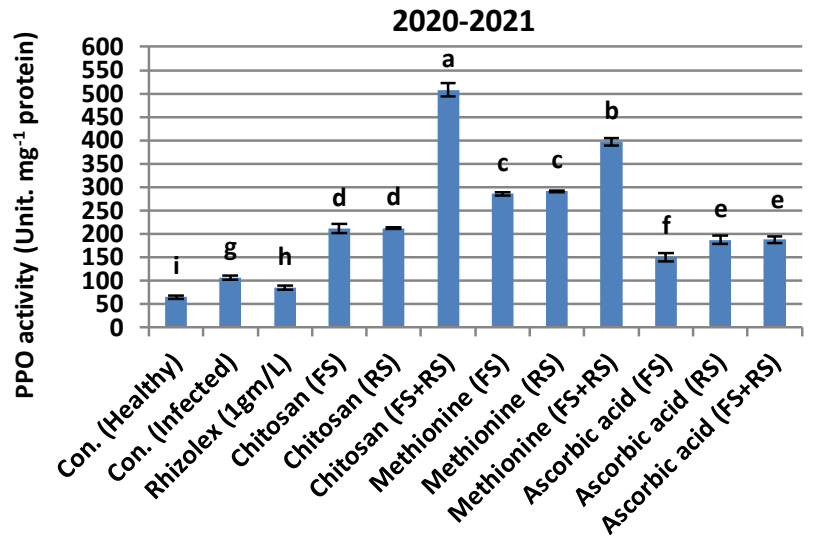

Treatments

Fig 10. Effect of some natural substrates on PPO activity in infected strawberry with Rhizoctonia solani during two seasons 2019/2020 and 2020/2021.
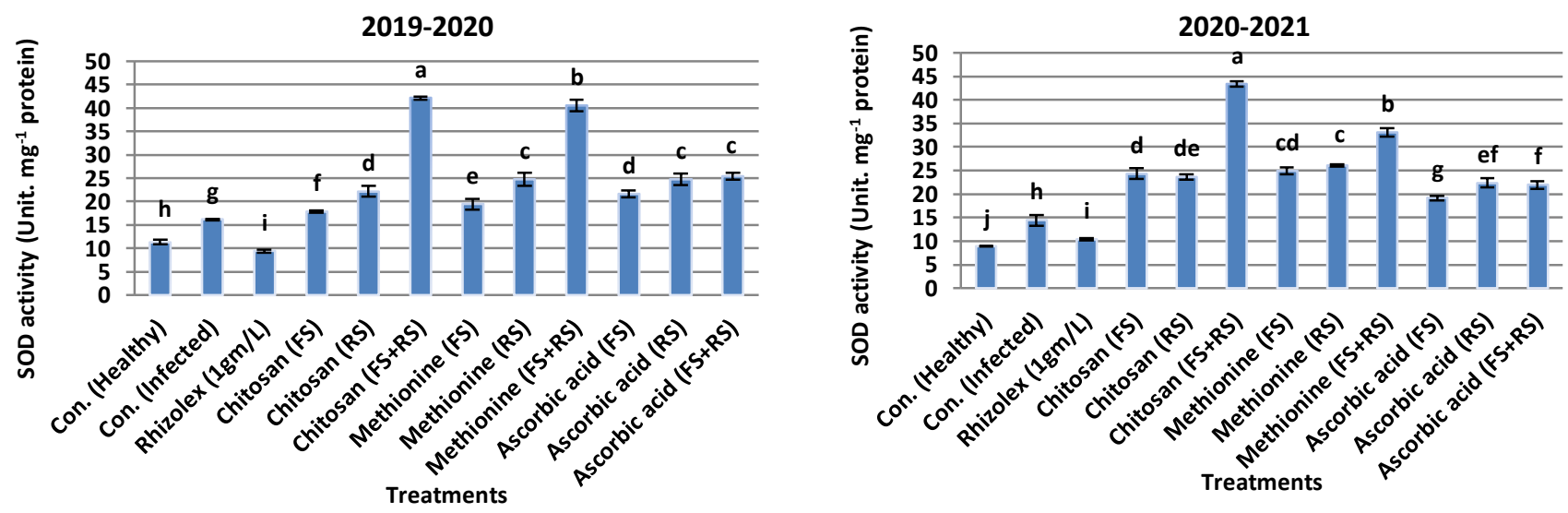

Fig 11.Effect of some natural substrates on SOD activity in infected strawberry with Rhizoctonia solani during two seasons 2019/2020 and 2020/2021.
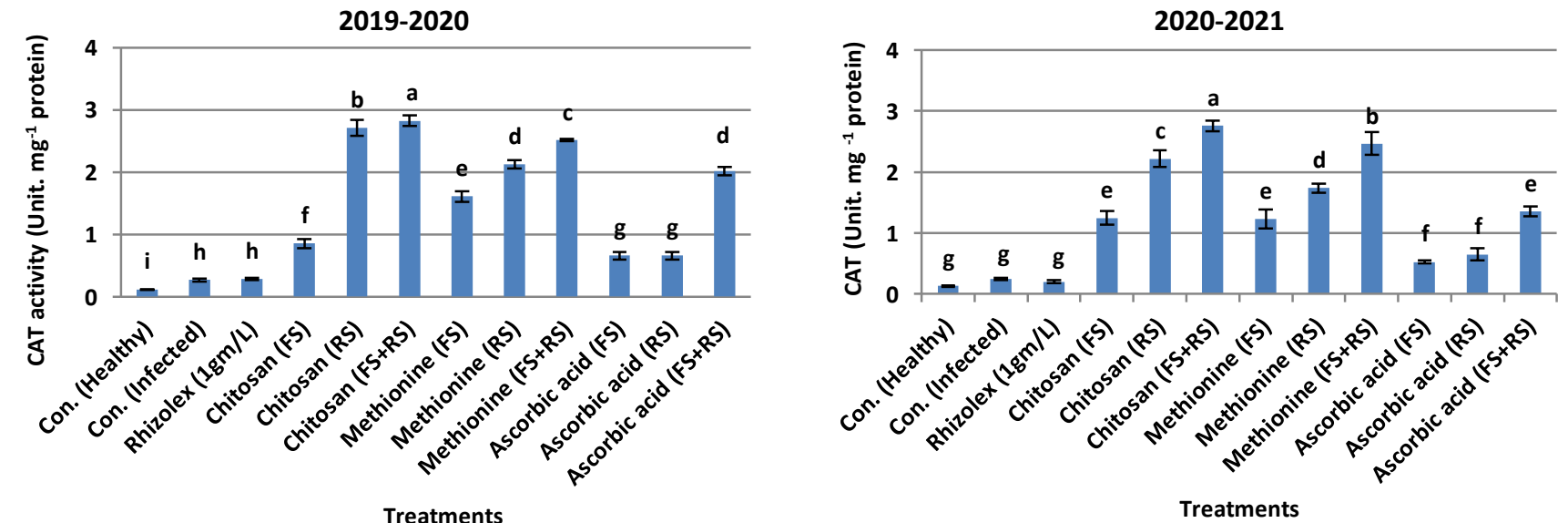

Fig 12. Effect of some natural substrates on CAT activity in infected strawberry with Rhizoctonia solani during two seasons 2019/2020 and 2020/2021. 


\section{Scientific Journal of Agricultural Sciences 3 (2): 40-0, 2021}

Our results are supported by previous studies reported that L-methionine and riboflavin induced the plant resistance against powdery mildew infection in strawberry, squash, melon, cantaloupe and pea (Tzeng et al., 1996; Wang and Tzeng, 1998; Sarosh et al., 2005). another study indicated that L-methionine induced plant resistance against Xanthomonas citri sub.sp. citri which led to significant reduction of disease severity by changes in $\beta$-1,3-glucanase transcript levels and increasing the activity of antioxidant enzymes i.e., catalase, peroxidase, and phenylalanine ammonia-lyase (Hasabi et al., 2014).

Ascorbic acid (AA) is an antioxidant molecule and acts as substrate for the detoxification of reactive oxygen species (Akram et al., 2017) that protecting plant cells from plant pathogens attacks (SomaiJemmali et al., 2015; Boubakri, 2017). Pre-planting seedlings of marjoram plants treated with some mineral compounds and antioxidants including ascorbic acid reduced the disease incidence of root rot and wilt diseases caused by Rhizoctonia solani, Sclerotinia sclerotiorum and Fusarium xysporum (Ahmed et al., 2017). Besides its AA role in inducing plant resistance, also it has a direct effect as antifungal. In this regard, Botanga et al. (2012) reported that AA has direct effect on the hyphal development of Alternaria brassicicola. Overall, our results indicated that $\mathrm{AA}$ have a role in induced plant resistance.

\subsubsection{Vegetative growth characteristics}

In greenhouse experiments, data in Fig. (13) and Table (2), clarified that all applications with chitosan, methionine and ascorbic acid or application with Rhizolex significantly improved all growth characters (plant high, fresh and dry weight of shoot or root, number of leaves, crown diameter) compared with untreated (infected or not infected) plants. The combined between foliar spray and seedling root soaking of chitosan or methionine have the highest growth characters.

In the field experiments, it is clear from data in Table (3) that soaking the transplants roots, foliar or both together with safety compounds (chitosan at 500 ppm, methionine at $20 \mathrm{ppm}$ and ascorbic acid at 20 $\mathrm{mM}$ ) significantly enhanced all studied morphological traits of strawberry plants i.e., plant height, plant fresh weight, plant dry weight, number of leaves, number of crown per plant and crown diameter during the first and second seasons of study compared with the control and fungicide (Rhizolex $1 \mathrm{~g} / \mathrm{L}$ ). In this regard, soaking plus foliar spraying with chitosan at $500 \mathrm{ppm}$ gave the highest value for plant height, plant fresh weight, plant dry weight, number of crown and crown diameter in two seasons while, methionine at $20 \mathrm{ppm}$ (soaking plus foliar spraying) reflected the highest values for number of leaves in both seasons. Also, ascorbic acid (soaking plus foliar spraying) increased the root fresh and dry weight per plant in first and second seasons. The increase in growth due to the application of tested stimulants may be attributed to the role of such materials as antioxidants which contract the free radical $\left(\mathrm{O}_{2}\right)$ which affect the activity and viability of plant cells. Furthermore, increasing the growth duration and retardation of plant senescence. In addition, the superiority of chitosan, methionine and ascorbic acid may be due to its role as a source of growth promoting substances which affect plant cells division and elongation and in turn increased plant growth. Chitosan, plays main role in enhancement plant metabolism phytoprotection and maintain plant health and consequently increase plant growth. Also, the effect of chitosan on increasing key enzymes activity of nitrogen metabolism, which enhanced plant growth and development (Mondal et al., 2012). The amino acids which play an important role in plant metabolism and protein assimilation necessary for cells formation and consequently increased fresh and dry matter of plant which are good indicator for plant growth. Ascorbic acid shares in regulation of cell division and growth involving in signal transduction in plants through using multiple pathways for to synthesizing ascorbic acid, which reflects the importance of this molecule for plant health. This result agree with those of El-Miniawy et al. (2013), Shams et al. (2014) and Nithin et al. (2020) on strawberry; they found that foliar concentration of chitosan increased vegetative growth characteristics (plant height, number of leaves/ plants, leaf area and fresh and dry weight per plant) compared with control. Also, Gad El-Hak et al. (2012) stated that foliar spray with $20 \mathrm{mM}$ ascorbic acid increased pea plant height, number of branches and plant dry weight. In addition, Manal et al. (2019) reported that amino acids application increased strawberry leaves number and shoot dry weight/plant. Also, Fatma and Hanaa (2020) on strawberry found that spraying strawberry plants with mixture of tryptophan and methionine led to an increase in vegetative growth characteristics. 
S. M. Rizk and Maha H. Mohamed., 2021

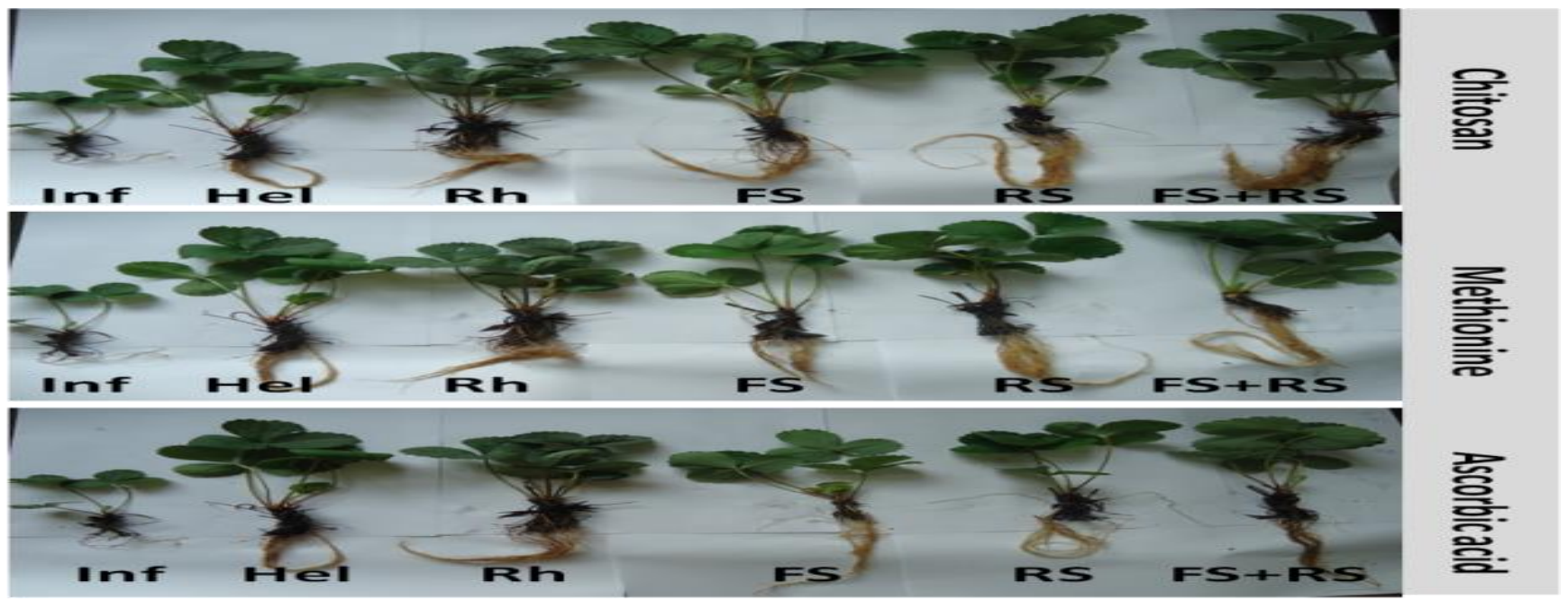

Fig 13. Effect of different abiotic inducer treatments on growth parameters of strawberry infected with Rhizoctonia solani. Inf: infected plants, Hel: healthy plants, Rh: Rhizolex, FS: foliar spray, RS: root soaking.

Table 2. Effect of different abiotic inducer treatments on growth parameters of strawberry infected with Rhizoctonia solani during (2019-2020/2020-2021) seasons.

\begin{tabular}{|c|c|c|c|c|c|c|c|}
\hline \multirow{2}{*}{ Treatments } & \multirow{2}{*}{$\begin{array}{l}\text { Plant } \\
\text { height } \\
\text { (cm) }\end{array}$} & \multicolumn{2}{|c|}{ Shoot weight (g) } & \multirow{2}{*}{$\begin{array}{c}\text { No. of } \\
\text { leaves/plant }\end{array}$} & \multirow{2}{*}{$\begin{array}{l}\text { Crown } \\
\text { diameter } \\
\text { (cm) }\end{array}$} & \multicolumn{2}{|c|}{ Root weight (g) } \\
\hline & & fresh & dry & & & fresh & dry \\
\hline \multicolumn{8}{|c|}{ 2019-2020 } \\
\hline Control (Healthy plants) & $16.50 \mathrm{~d}$ & $38.13 \mathrm{ef}$ & 8.06de & $10.50 \mathrm{cde}$ & $1.26 f$ & $16.65 \mathrm{e}$ & $3.78 \mathrm{~d}$ \\
\hline Control(Infected plants) & $10.85 \mathrm{f}$ & $21.76 \mathrm{i}$ & $5.73 \mathrm{~g}$ & $7.33 \mathrm{~h}$ & $0.96 \mathrm{~h}$ & $10.10 \mathrm{~g}$ & $2.21 \mathrm{f}$ \\
\hline $\operatorname{Rhizolex}(1 \mathrm{~g} / \mathrm{L})$ & $15.06 \mathrm{e}$ & $30.06 \mathrm{~h}$ & $6.41 \mathrm{f}$ & $9.16 \mathrm{fg}$ & $1.08 \mathrm{~g}$ & $14.11 \mathrm{f}$ & $2.91 \mathrm{e}$ \\
\hline Chitosan (FS) & $18.21 \mathrm{bc}$ & $38.91 \mathrm{e}$ & $8.48 \mathrm{~d}$ & $11.16 \mathrm{c}$ & $1.61 \mathrm{bc}$ & $21.60 \mathrm{c}$ & $4.30 \mathrm{c}$ \\
\hline Chitosan (RS) & $18.36 b c$ & $48.98 b$ & $10.81 \mathrm{~b}$ & $12.00 \mathrm{~b}$ & $1.65 b$ & $23.11 b$ & $4.26 c$ \\
\hline Chitosan (FS+Rs) & $21.00 \mathrm{a}$ & $53.50 \mathrm{a}$ & $11.4 \mathrm{a}$ & $13.16 \mathrm{a}$ & $1.81 \mathrm{a}$ & $23.86 \mathrm{a}$ & $4.96 a$ \\
\hline Methionine (FS) & $17.86 \mathrm{c}$ & $42.63 d$ & $9.28 \mathrm{c}$ & $9.66 \mathrm{ef}$ & $1.45 \mathrm{de}$ & $21.36 \mathrm{c}$ & $4.18 \mathrm{c}$ \\
\hline Methionine (RS) & $18.50 \mathrm{bc}$ & $43.20 \mathrm{~d}$ & $9.46 \mathrm{c}$ & 10.16de & $1.50 \mathrm{cde}$ & $21.35 \mathrm{c}$ & $4.66 \mathrm{~b}$ \\
\hline Methionine (FS+RS) & $19.00 \mathrm{~b}$ & $45.73 \mathrm{c}$ & $9.76 \mathrm{c}$ & $10.83 \mathrm{~cd}$ & $1.60 \mathrm{bc}$ & $22.71 b$ & $4.75 \mathrm{ab}$ \\
\hline Ascorbic acid (FS) & $15.81 \mathrm{de}$ & $35.91 \mathrm{~g}$ & $7.71 \mathrm{e}$ & $8.66 \mathrm{~g}$ & $1.40 \mathrm{e}$ & $20.35 d$ & $4.40 \mathrm{c}$ \\
\hline Ascorbic acid (RS) & $16.45 \mathrm{~d}$ & $36.60 \mathrm{fg}$ & $8.23 \mathrm{~d}$ & $9.00 \mathrm{fg}$ & $1.50 \mathrm{cde}$ & $21.53 \mathrm{c}$ & $4.83 \mathrm{ab}$ \\
\hline Ascorbic acid (FS+RS) & \multicolumn{6}{|c|}{$2020-2021$} & $4.86 \mathrm{ab}$ \\
\hline Control (Healthy plants) & $16.33 \mathrm{e}$ & $32.56 \mathrm{e}$ & $8.13 \mathrm{e}$ & $10.33 b$ & $1.23 \mathrm{e}$ & $14.46 \mathrm{e}$ & $3.20 \mathrm{~d}$ \\
\hline Control(Infected plants) & $10.16 \mathrm{~g}$ & $19.00 \mathrm{~g}$ & $5.63 \mathrm{~g}$ & $6.33 d$ & $1.00 \mathrm{f}$ & $9.20 \mathrm{f}$ & $2.03 \mathrm{e}$ \\
\hline Rhizolex $(1 \mathrm{~g} / \mathrm{L})$ & $14.16 \mathrm{f}$ & $28.66 \mathrm{f}$ & $6.86 \mathrm{f}$ & $8.00 \mathrm{c}$ & $1.00 \mathrm{f}$ & $14.10 \mathrm{e}$ & $2.30 \mathrm{e}$ \\
\hline Chitosan (FS) & $18.66 \mathrm{bc}$ & $35.16 \mathrm{de}$ & $8.16 \mathrm{e}$ & $10.33 b$ & $1.63 \mathrm{ab}$ & $19.13 \mathrm{~cd}$ & $4.00 \mathrm{c}$ \\
\hline Chitosan (RS) & $19.66 b$ & $37.80 \mathrm{bcd}$ & $10.63 b c$ & $11.00 \mathrm{~b}$ & $1.63 \mathrm{ab}$ & $20.96 b c$ & $4.50 \mathrm{ab}$ \\
\hline Chitosan (FS+Rs) & $21.33 \mathrm{a}$ & $47.40 \mathrm{a}$ & $13.53 \mathrm{a}$ & $12.33 \mathrm{a}$ & $1.73 \mathrm{a}$ & $24.20 \mathrm{a}$ & $4.86 \mathrm{a}$ \\
\hline Methionine (FS) & $18.00 \mathrm{~cd}$ & $38.96 b c$ & $9.70 \mathrm{~cd}$ & $10.33 b$ & $1.46 \mathrm{c}$ & $19.03 \mathrm{~cd}$ & $4.00 \mathrm{c}$ \\
\hline Methionine (RS) & $18.66 \mathrm{bc}$ & $38.53 \mathrm{bcd}$ & $9.76 \mathrm{~cd}$ & $10.66 \mathrm{~b}$ & $1.46 \mathrm{c}$ & $19.53 \mathrm{~cd}$ & $4.06 b c$ \\
\hline Methionine (FS+RS) & $19.00 \mathrm{bc}$ & $39.80 \mathrm{~b}$ & $11.00 \mathrm{~b}$ & $10.66 \mathrm{~b}$ & $1.53 \mathrm{bc}$ & $22.43 \mathrm{ab}$ & $4.86 \mathrm{a}$ \\
\hline Ascorbic acid (FS) & $16.00 \mathrm{e}$ & $32.96 \mathrm{e}$ & $7.86 \mathrm{ef}$ & $10.33 b$ & $1.26 \mathrm{de}$ & $17.16 \mathrm{~d}$ & $3.60 \mathrm{~cd}$ \\
\hline Ascorbic acid (RS) & $16.16 \mathrm{e}$ & 34.90de & $8.30 \mathrm{e}$ & $11.00 \mathrm{~b}$ & $1.26 \mathrm{de}$ & $17.63 d$ & $3.83 \mathrm{c}$ \\
\hline Ascorbic acid (FS+RS) & 17.16de & $35.86 \mathrm{cde}$ & 8.70de & $10.33 b$ & $1.40 \mathrm{~cd}$ & $18.30 \mathrm{~cd}$ & $3.96 \mathrm{c}$ \\
\hline
\end{tabular}


Table 3. Effect of some natural compounds (chitosan, methionine and ascorbic acid) on vegetative characteristics of strawberry plants cv. Festival during 2019/2020 and 2020/2021 seasons.

\begin{tabular}{|c|c|c|c|c|c|c|c|c|}
\hline \multirow[t]{2}{*}{ Treatments } & \multirow{2}{*}{$\begin{array}{c}\text { Plant } \\
\text { height } \\
(\mathrm{cm})\end{array}$} & \multicolumn{2}{|c|}{ Plant weight (g) } & \multicolumn{2}{|c|}{ Number } & \multirow{2}{*}{$\begin{array}{c}\text { Crown } \\
\text { diameter } \\
(\mathrm{cm})\end{array}$} & \multicolumn{2}{|c|}{ Root weight (g) } \\
\hline & & Fresh & Dry & Leaves & Crowns & & Fresh & Dry \\
\hline \multicolumn{9}{|c|}{$2019 / 2020$} \\
\hline Control & $19.67 \mathrm{~d}$ & $54.55 \mathrm{e}$ & $12.27 \mathrm{~h}$ & $18.50 \mathrm{~d}$ & $2.57 \mathrm{~d}$ & $2.43 \mathrm{c}$ & $18.29 \mathrm{f}$ & $4.45 \mathrm{c}$ \\
\hline Rhizolex (1g/L) & $20.17 \mathrm{~d}$ & $55.20 \mathrm{e}$ & $12.94 \mathrm{gh}$ & $18.50 \mathrm{~d}$ & $3.00 \mathrm{~cd}$ & $2.50 \mathrm{bc}$ & $18.61 \mathrm{ef}$ & $4.67 \mathrm{bc}$ \\
\hline Chitosan (FS) & $21.66 \mathrm{abc}$ & $57.89 \mathrm{de}$ & $14.51 \mathrm{fg}$ & $20.33 \mathrm{bc}$ & $3.50 \mathrm{abc}$ & $2.63 \mathrm{abc}$ & 18.79def & $4.73 \mathrm{bc}$ \\
\hline Chitosan (RS) & $20.83 \mathrm{bcd}$ & $68.38 \mathrm{bc}$ & $17.49 \mathrm{bc}$ & $19.67 \mathrm{bcd}$ & $3.70 \mathrm{abc}$ & $2.60 \mathrm{bc}$ & $19.40 \mathrm{c}$ & $5.11 \mathrm{ab}$ \\
\hline Chitosan (FS+Rs) & $22.50 \mathrm{a}$ & $73.95 \mathrm{a}$ & $20.39 \mathrm{a}$ & $20.68 \mathrm{~b}$ & $3.93 \mathrm{a}$ & $2.87 \mathrm{a}$ & $21.29 \mathrm{a}$ & $5.22 \mathrm{a}$ \\
\hline Methionine (FS) & $21.83 \mathrm{abc}$ & $65.56 \mathrm{c}$ & $16.27 \mathrm{cde}$ & $19.33 \mathrm{bcd}$ & $3.33 \mathrm{a}-\mathrm{d}$ & $2.53 \mathrm{bc}$ & $20.07 \mathrm{~b}$ & $5.05 \mathrm{ab}$ \\
\hline Methionine (RS) & $21.67 \mathrm{abc}$ & $65.80 \mathrm{c}$ & $17.03 \mathrm{bcd}$ & $18.66 \mathrm{~d}$ & $3.51 \mathrm{abc}$ & $2.60 \mathrm{bc}$ & 19.00cde & $4.85 \mathrm{abc}$ \\
\hline $\begin{array}{l}\text { Methionine } \\
\text { (FS+RS) }\end{array}$ & $22.16 \mathrm{a}$ & $70.65 \mathrm{ab}$ & $19.66 \mathrm{a}$ & $22.67 \mathrm{a}$ & $3.96 \mathrm{a}$ & $2.63 \mathrm{abc}$ & $21.29 \mathrm{a}$ & $5.19 \mathrm{a}$ \\
\hline Ascorbic acid (FS) & $20.66 \mathrm{~cd}$ & $65.47 \mathrm{c}$ & $15.49 \mathrm{def}$ & $19.00 \mathrm{~cd}$ & $3.03 \mathrm{bcd}$ & $2.70 \mathrm{ab}$ & $19.33 \mathrm{~cd}$ & $4.90 \mathrm{ab}$ \\
\hline Ascorbic acid (RS) & $21.50 \mathrm{abc}$ & $60.95 \mathrm{~d}$ & $14.86 \mathrm{ef}$ & $19.34 \mathrm{bcd}$ & $3.57 \mathrm{abc}$ & $2.50 \mathrm{bc}$ & $19.41 \mathrm{c}$ & $4.96 \mathrm{ab}$ \\
\hline $\begin{array}{l}\text { Ascorbic acid } \\
\text { (FS+RS) }\end{array}$ & $22.00 \mathrm{ab}$ & 71.73ab & $18.73 \mathrm{ab}$ & $20.67 \mathrm{~b}$ & $3.83 \mathrm{ab}$ & $2.67 \mathrm{abc}$ & $21.48 \mathrm{a}$ & $5.26 \mathrm{a}$ \\
\hline \multicolumn{9}{|c|}{$2020 / 2021$} \\
\hline Control & $24.00 \mathrm{c}$ & $64.96 \mathrm{~g}$ & $16.09 \mathrm{f}$ & $19.67 \mathrm{e}$ & $2.25 \mathrm{c}$ & $2.05 \mathrm{e}$ & $19.62 \mathrm{~d}$ & $4.51 \mathrm{e}$ \\
\hline Rhizolex (1g/L) & $24.33 \mathrm{bc}$ & $80.96 \mathrm{f}$ & $19.62 \mathrm{e}$ & $21.00 \mathrm{e}$ & $3.17 \mathrm{~b}$ & $2.23 \mathrm{de}$ & $19.67 \mathrm{~d}$ & $4.90 \mathrm{de}$ \\
\hline Chitosan (FS) & $25.17 \mathrm{abc}$ & $86.11 \mathrm{de}$ & $24.81 \mathrm{ab}$ & $24.99 \mathrm{bc}$ & $3.16 \mathrm{~b}$ & $2.43 \mathrm{~cd}$ & $20.67 \mathrm{bc}$ & $5.06 \mathrm{bcd}$ \\
\hline Chitosan (RS) & $25.00 \mathrm{abc}$ & $90.14 \mathrm{c}$ & $24.68 \mathrm{~b}$ & $24.66 \mathrm{bc}$ & $3.40 \mathrm{ab}$ & $2.65 \mathrm{abc}$ & $21.40 \mathrm{~b}$ & $5.36 \mathrm{abc}$ \\
\hline Chitosan (FS+Rs) & $26.16 \mathrm{a}$ & $97.70 \mathrm{a}$ & $26.98 \mathrm{a}$ & $25.60 \mathrm{ab}$ & $3.70 \mathrm{ab}$ & $2.86 \mathrm{a}$ & $22.29 \mathrm{a}$ & $5.46 \mathrm{ab}$ \\
\hline Methionine (FS) & $24.33 \mathrm{bc}$ & $83.25 \mathrm{ef}$ & $22.08 \mathrm{~cd}$ & $24.53 b c$ & $3.43 \mathrm{ab}$ & $2.54 \mathrm{bc}$ & $20.70 \mathrm{bc}$ & $5.11 \mathrm{bcd}$ \\
\hline Methionine (RS) & $24.67 \mathrm{abc}$ & $87.04 \mathrm{~cd}$ & $24.40 \mathrm{bc}$ & $23.00 \mathrm{~d}$ & $3.57 \mathrm{ab}$ & $2.45 \mathrm{~cd}$ & $20.62 \mathrm{c}$ & $4.97 \mathrm{~cd}$ \\
\hline $\begin{array}{l}\text { Methionine } \\
\text { (FS+RS) }\end{array}$ & $26.00 \mathrm{a}$ & $97.57 \mathrm{a}$ & $26.58 \mathrm{ab}$ & $26.90 \mathrm{a}$ & $3.90 \mathrm{a}$ & $2.75 \mathrm{ab}$ & $22.29 \mathrm{a}$ & $5.46 \mathrm{ab}$ \\
\hline Ascorbic acid (FS) & $24.33 \mathrm{bc}$ & $81.20 \mathrm{f}$ & $20.05 \mathrm{de}$ & $24.07 \mathrm{~cd}$ & $3.33 \mathrm{ab}$ & $2.57 \mathrm{bc}$ & $20.12 \mathrm{~cd}$ & $4.96 \mathrm{~cd}$ \\
\hline Ascorbic acid (RS) & $25.17 \mathrm{abc}$ & $93.98 \mathrm{~b}$ & $25.68 \mathrm{ab}$ & $25.00 \mathrm{bc}$ & $3.50 \mathrm{ab}$ & $2.40 \mathrm{~cd}$ & $19.77 \mathrm{~d}$ & $5.06 \mathrm{bcd}$ \\
\hline $\begin{array}{l}\text { Ascorbic acid } \\
\text { (FS+RS) }\end{array}$ & $25.83 \mathrm{ab}$ & $96.51 \mathrm{ab}$ & $26.29 \mathrm{ab}$ & $25.03 \mathrm{bc}$ & $3.67 \mathrm{ab}$ & $2.65 \mathrm{a}-\mathrm{c}$ & $22.81 \mathrm{a}$ & $5.68 \mathrm{a}$ \\
\hline
\end{tabular}

\subsubsection{Chemical composition of plant foliage}

As for the effect of tested natural compounds (chitosan, methionine and ascorbic acid) on total nitrogen, phosphorus, potassium and carbohydrates concentration in plant foliage of strawberry plant, data in Table (4) indicate that (soaking plus foliar spraying) strawberry plants with such safety compounds significantly affected total phosphorus, potassium both seasons. However, it did not significantly affect total nitrogen content during both seasons and total carbohydrates only during the second one. In this regard, soaking and foliar together application of methionine, chitosan and ascorbic acid at $20 \mathrm{ppm}, 500$ ppm and $20 \mathrm{mM}$ respectively, exhibited the highest values of $\mathrm{N}, \mathrm{P}, \mathrm{K}$ and carbohydrates in plants compared with the control. Such results are true during the two seasons of growth. In this connection, the promoting effects of growth stimulants on the concentration of macro- elements was connected with its positive effects on vegetative growth parameters (Table 1). Moreover, such increasing tendency of $\mathrm{N}$, $\mathrm{P}, \mathrm{K}$ and carbohydrates as a result of studied growth stimulants may be attributed to its main role on the enzymes which may control the active absorption of nutrients and water from the soil. Obtained results are in the same line with those reported by Ramadan and Mohamed (2015) on okra and Dawa et al. (2017) on 
S. M. Rizk and Maha H. Mohamed., 2021

Table 4. Effect of some natural compounds i.e. chitosan, methionine and ascorbic acid on chemical composition of plant foliage of strawberry plants cv. Festival during 2019/2020 and 2020/2021 seasons.

\begin{tabular}{|c|c|c|c|c|c|c|c|c|}
\hline \multirow[b]{2}{*}{ Treatments } & \multicolumn{4}{|c|}{$2019 / 2020$} & \multicolumn{4}{|c|}{$2020 / 2021$} \\
\hline & $\mathbf{N \%}$ & $\mathbf{P \%}$ & $\mathbf{K} \%$ & $\begin{array}{c}\text { Carbohydrates } \\
\text { (g/100g d.w) }\end{array}$ & $\mathbf{N \%}$ & $\mathbf{P \%}$ & $\mathbf{K} \%$ & $\begin{array}{c}\text { Carbohydrates } \\
\text { (g/100g d.w) }\end{array}$ \\
\hline Control & $2.61 \mathrm{a}$ & $0.43 \mathrm{c}$ & $1.43 \mathrm{~d}$ & $13.36 \mathrm{~d}$ & $2.44 a$ & $0.32 \mathrm{~d}$ & $1.22 \mathrm{c}$ & $14.23 \mathrm{a}$ \\
\hline Rhizolex (1g/L) & $2.62 \mathrm{a}$ & $0.55 b$ & $1.43 \mathrm{~d}$ & $13.98 \mathrm{~d}$ & $2.44 \mathrm{a}$ & $0.34 \mathrm{~cd}$ & $1.26 \mathrm{bc}$ & $14.32 \mathrm{a}$ \\
\hline Chitosan (FS) & $2.63 a$ & $0.55 b$ & $1.45 \mathrm{~cd}$ & $15.40 \mathrm{bc}$ & $2.47 \mathrm{a}$ & $0.37 \mathrm{~cd}$ & $1.27 \mathrm{bc}$ & $14.38 \mathrm{a}$ \\
\hline Chitosan (RS) & $2.62 \mathrm{a}$ & $0.57 \mathrm{~b}$ & $1.46 \mathrm{~cd}$ & $15.18 \mathrm{bc}$ & $2.46 \mathrm{a}$ & $0.41 \mathrm{abc}$ & $1.33 \mathrm{ab}$ & $14.45 \mathrm{a}$ \\
\hline Chitosan (FS+Rs) & $2.67 \mathrm{a}$ & $0.68 \mathrm{a}$ & $1.58 \mathrm{ab}$ & $16.12 \mathrm{ab}$ & $2.50 \mathrm{a}$ & $0.47 \mathrm{a}$ & $1.37 \mathrm{a}$ & $14.80 \mathrm{a}$ \\
\hline Methionine (FS) & $2.63 \mathrm{a}$ & $0.56 \mathrm{~b}$ & $1.49 \mathrm{~cd}$ & $15.89 a b c$ & $2.47 \mathrm{a}$ & $0.38 \mathrm{bcd}$ & $1.26 \mathrm{bc}$ & $14.36 \mathrm{a}$ \\
\hline Methionine (RS) & $2.65 \mathrm{a}$ & $0.57 \mathrm{~b}$ & $1.47 \mathrm{~cd}$ & $15.069 \mathrm{c}$ & $2.46 \mathrm{a}$ & $0.42 \mathrm{abc}$ & $1.27 \mathrm{bc}$ & $14.40 \mathrm{a}$ \\
\hline $\begin{array}{l}\text { Methionine } \\
\text { (FS+RS) }\end{array}$ & $2.67 \mathrm{a}$ & $0.73 \mathrm{a}$ & $1.63 \mathrm{a}$ & $16.735 \mathrm{a}$ & $2.54 \mathrm{a}$ & $0.48 \mathrm{a}$ & $1.38 \mathrm{a}$ & $14.89 \mathrm{a}$ \\
\hline $\begin{array}{l}\text { Ascorbic acid } \\
\text { (FS) }\end{array}$ & $2.64 a$ & $0.55 b$ & $1.47 \mathrm{~cd}$ & $15.27 \mathrm{bc}$ & $2.46 a$ & $0.36 \mathrm{~cd}$ & $1.32 \mathrm{ab}$ & $14.44 \mathrm{a}$ \\
\hline Ascorbic acid(RS) & $2.66 \mathrm{a}$ & $0.57 b$ & $1.46 \mathrm{~cd}$ & $14.98 \mathrm{c}$ & $2.45 \mathrm{a}$ & $0.41 \mathrm{abc}$ & $1.31 \mathrm{ab}$ & $14.60 \mathrm{a}$ \\
\hline $\begin{array}{l}\text { Ascorbic acid } \\
\text { (FS+RS) }\end{array}$ & $2.66 a$ & $0.68 \mathrm{a}$ & $1.51 b c$ & $16.10 \mathrm{ab}$ & $2.48 \mathrm{a}$ & $0.46 \mathrm{ab}$ & $1.37 \mathrm{a}$ & $14.71 \mathrm{a}$ \\
\hline
\end{tabular}

tomato, they found that foliar spray of chitosan resulted in increasing the percentages of $\mathrm{N}, \mathrm{P}$ and $\mathrm{K}$ in leaves. Also, Abo Sedera et al. (2010) and Mohamed (2015) on strawberry found that foliar application of amino acid resulted in increasing the percentages of $\mathrm{N}$, $\mathrm{P}, \mathrm{K}$ and carbohydrates in leaves. However, Shadia (2017) on potato and Anany and Ismail (2020) on common bean reported that ascorbic acid foliar application increased $\mathrm{N}, \mathrm{P}, \mathrm{K}$ and carbohydrates in plant.

\subsubsection{Fruit yield and its components}

Concerning the effect of soaking transplants roots before planting and spraying strawberry plants with natural compounds i.e., chitosan' methionine and ascorbic acid on total produced fruit yield and its components expressed as early yield, exportable, marketable and total yield either per plant or feddan as well as unmarketable yield.

Data recorded in Table (5) show that soaking transplants roots before planting for 15 minutes plus foliar spraying the plants five times during the growing seasons chitosan at $500 \mathrm{ppm}$ exhibited the highest values in all determined yield parameters compared with all treatments during both seasons of this experiment. However, no significant differences were noticed among the used levels of chitosan, methionine and ascorbic acid (soaking plus foliar spraying) in all measured yield parameters during both seasons of study. In this regard, the highest values of un marketable fruit yield was recorded in case of the control treatment. However, the increments in total produced yield and its components as a result of using chitosan' methionine and ascorbic acid were connected with the increase in vegetative growth parameters (Table 3). In addition, it's effect on increasing macro- nutrients (Table 4) which affected plant growth and in turn increased its productivity. Also, using such growth enhancers reduce the proportion of infected fruit and the number of days to reach flower synthesis, resulting in an increase in the early and marketable yield. The obtained results are similar to those reported by El-Miniawy et al. (2013), Shams et al. (2014) and Nithin et al. (2020) on strawberry, they found that the foliar application of chitosan increased the yield and also, Shadia (2017) and Anany and Ismail (2020) on common bean, they found that the use of ascorbic acid led to an increase in the yield.. However, Manal et al. (2019) on strawberry and Fatma and Hanaa (2020) on potato reported that spraying strawberry plants with amino acids increased yield. 
Scientific Journal of Agricultural Sciences 3 (2): 40-0, 2021

Table 5. Effect of some natural compounds, i.e., chitosan, methionine and ascorbic acid on total fruit yield and its components of strawberry plants cv. Festival during 2019/2020 and 2020/2021 seasons.

\begin{tabular}{|c|c|c|c|c|c|c|}
\hline Treatments & $\begin{array}{l}\text { Early } \\
\text { yield } \\
\text { (ton/fed) }\end{array}$ & $\begin{array}{l}\text { Exportable } \\
\text { yield } \\
\text { (ton/fed) }\end{array}$ & $\begin{array}{l}\text { Marketable } \\
\text { yield } \\
\text { (ton/fed) }\end{array}$ & $\begin{array}{l}\text { Unmarketable } \\
\text { yield(kg/fed) }\end{array}$ & $\begin{array}{l}\text { Total yield } \\
\text { (g/plant) }\end{array}$ & $\begin{array}{l}\text { Total } \\
\text { Yield } \\
\text { (t/fed) }\end{array}$ \\
\hline \multicolumn{7}{|c|}{$2019 / 2020$} \\
\hline control & $4.384 \mathrm{e}$ & $2.83 \mathrm{e}$ & $16.113 \mathrm{c}$ & $766.50 \mathrm{a}$ & $421.99 \mathrm{c}$ & $16.879 \mathrm{c}$ \\
\hline Rhizolex (1g/L) & $5.438 \mathrm{~d}$ & $3.02 \mathrm{~d}$ & $17.184 \mathrm{bc}$ & $720.67 \mathrm{~b}$ & $447.62 \mathrm{bc}$ & $17.905 \mathrm{bc}$ \\
\hline Chitosan (FS) & $5.846 \mathrm{bc}$ & $3.72 \mathrm{c}$ & $18.308 \mathrm{ab}$ & $571.83 \mathrm{~g}$ & $472.00 \mathrm{ab}$ & $18.880 \mathrm{ab}$ \\
\hline Chitosan (RS) & $5.841 \mathrm{bc}$ & $3.84 \mathrm{~b}$ & $17.371 \mathrm{bc}$ & $585.37 \mathrm{fg}$ & $448.91 \mathrm{bc}$ & $17.956 \mathrm{bc}$ \\
\hline Chitosan (FS+Rs) & $6.902 \mathrm{a}$ & $4.66 \mathrm{a}$ & $19.253 \mathrm{a}$ & $566.90 \mathrm{~g}$ & $495.50 \mathrm{a}$ & $19.820 \mathrm{a}$ \\
\hline Methionine (FS) & $6.614 \mathrm{a}$ & $3.71 \mathrm{c}$ & $18.239 \mathrm{ab}$ & $655.93 \mathrm{~cd}$ & $472.37 \mathrm{ab}$ & $18.895 \mathrm{ab}$ \\
\hline Methionine (RS) & $5.654 \mathrm{bcd}$ & $3.71 \mathrm{c}$ & $17.371 \mathrm{bc}$ & $668.27 \mathrm{c}$ & $450.98 \mathrm{bc}$ & $18.039 \mathrm{bc}$ \\
\hline Methionine (FS+RS) & $6.725 \mathrm{a}$ & $4.61 \mathrm{a}$ & $18.398 \mathrm{ab}$ & 617.33 ef & $475.38 \mathrm{ab}$ & $19.015 \mathrm{ab}$ \\
\hline Ascorbic acid (FS) & $6.008 \mathrm{~b}$ & $3.70 \mathrm{c}$ & $18.289 \mathrm{ab}$ & $659.90 \mathrm{~cd}$ & $473.72 \mathrm{ab}$ & $18.949 \mathrm{ab}$ \\
\hline Ascorbic acid (RS) & $5.605 \mathrm{~cd}$ & $3.66 \mathrm{c}$ & $17.274 \mathrm{bc}$ & $680.80 \mathrm{c}$ & $448.87 \mathrm{bc}$ & $17.955 \mathrm{bc}$ \\
\hline Ascorbic acid(FS+RS) & $6.713 \mathrm{a}$ & $4.65 \mathrm{a}$ & $18.766 \mathrm{a}$ & $629.74 \mathrm{de}$ & $484.89 \mathrm{a}$ & $19.396 \mathrm{a}$ \\
\hline \multicolumn{7}{|c|}{$2020 / 2021$} \\
\hline control & $4.196 \mathrm{e}$ & $2.81 \mathrm{~d}$ & $15.183 \mathrm{~d}$ & $687.37 \mathrm{a}$ & $396.76 \mathrm{~d}$ & $15.870 \mathrm{~d}$ \\
\hline Rhizolex (1g/L) & $5.266 \mathrm{~d}$ & $2.97 \mathrm{c}$ & $16.894 \mathrm{c}$ & $669.27 \mathrm{ab}$ & $439.07 \mathrm{c}$ & $17.563 \mathrm{c}$ \\
\hline Chitosan (FS) & $5.408 \mathrm{bc}$ & $3.59 \mathrm{~b}$ & $17.948 \mathrm{abc}$ & $558.73 \mathrm{f}$ & $462.67 \mathrm{abc}$ & $18.507 \mathrm{abc}$ \\
\hline Chitosan (RS) & $5.367 \mathrm{~cd}$ & $3.64 \mathrm{~b}$ & $17.059 \mathrm{c}$ & $572.00 \mathrm{ef}$ & $440.82 \mathrm{c}$ & $17.633 \mathrm{c}$ \\
\hline Chitosan (FS+Rs) & $5.725 \mathrm{a}$ & $3.84 \mathrm{a}$ & $19.227 \mathrm{a}$ & $550.40 \mathrm{f}$ & $494.43 \mathrm{a}$ & $19.777 \mathrm{a}$ \\
\hline Methionine (FS) & $5.505 \mathrm{~b}$ & $3.65 \mathrm{~b}$ & $17.544 \mathrm{bd}$ & $626.33 \mathrm{bcd}$ & $454.26 \mathrm{bc}$ & $18.170 \mathrm{bc}$ \\
\hline Methionine (RS) & $5.419 \mathrm{bc}$ & $3.62 \mathrm{~b}$ & $17.056 \mathrm{c}$ & $677.47 \mathrm{ab}$ & $443.33 \mathrm{c}$ & $17.733 \mathrm{c}$ \\
\hline Methionine (FS+RS) & $5.699 \mathrm{a}$ & $3.79 \mathrm{a}$ & $18.119 \mathrm{abc}$ & $577.07 \mathrm{def}$ & $467.39 \mathrm{abc}$ & $18.696 \mathrm{abc}$ \\
\hline Ascorbic acid (FS) & $5.438 \mathrm{bc}$ & $3.61 \mathrm{~b}$ & $17.276 \mathrm{c}$ & $626.57 \mathrm{bcd}$ & $447.57 \mathrm{c}$ & $17.903 \mathrm{c}$ \\
\hline Ascorbic acid (RS) & $5.378 \mathrm{c}$ & $3.60 \mathrm{~b}$ & $16.999 \mathrm{c}$ & $654.67 \mathrm{abc}$ & $441.35 \mathrm{c}$ & $17.654 \mathrm{c}$ \\
\hline Ascorbic acid(FS+RS) & $5.668 \mathrm{a}$ & $3.79 \mathrm{a}$ & $18.775 \mathrm{ab}$ & 614.00 cde & $484.72 \mathrm{ab}$ & $19.389 \mathrm{ab}$ \\
\hline Within a column, means & tlonod & (rome & are not diffe & to $\mathrm{D}<05$ & & \\
\hline
\end{tabular}

\subsubsection{Physical Fruit quality}

Data presented in Table (6) show that soaking transplants roots before planting and spraying strawberry plants with natural compounds (chitosan at $500 \mathrm{ppm}$, methionine at $20 \mathrm{ppm}$ and ascorbic acid at $20 \mathrm{mM}$ ), significantly increased all measured fruit physical quality (average fruit weight, length, diameter and firmness) compared to the control in both seasons. In this respect, using soaking plus foliar spraying with chitosan at $500 \mathrm{ppm}$ ranked first followed by methionine at $20 \mathrm{ppm}$ (soaking plus foliar spraying) without significant differences among them. Obtained results are true during both seasons of study. Such increment in fruit parameters due to chitosan and methionine treatment may be attributed to the main role from chitosan and methionine on increasing the uptake of NPK (Table 4) which in turn increased fruit size. Similar observations were recorded by AbdelMawgoud et al. (2010) and Shafshak et al. (2011) for chitosan, El-Awadi et al. (2011), Manal et al. (2019) and Fatma and Hanaa (2020) for amino acids and Gad El-Hak et al. (2012), Shadia (2017) and Anany and Ismail (2020) for ascorbic acid.

\subsubsection{Chemical Fruit quality}

Data presented in Table (7) show that total soluble solids (T.S.S), vitamin C., total acidity, total sugars and anthocyanin content of fruits were significantly affected due to soaking the transplant roots, foliar spraying or both together in strawberry plants with natural compounds (chitosan at $500 \mathrm{ppm}$, methionine at $20 \mathrm{ppm}$ and ascorbic acid at $20 \mathrm{mM}$ ) compared with the control treatment in two seasons. In this connection, the highest value in all determined chemical constituents were recorded in case of soaking and foliar application together of ascorbic acid, methionine and chitosan at $20 \mathrm{mM}, 20 \mathrm{ppm}$ and $500 \mathrm{ppm}$ respectively. Obtained results were true during both seasons of study. Such results are coincided with those reported by Abdel-Mawgoud et 
Table 6. Effect of some natural compounds i.e. chitosan, methionine and ascorbic acid on physical fruit quality of strawberry plants cv. Festival during 2019/2020 and 2020/2021 seasons.

\begin{tabular}{|c|c|c|c|c|c|c|c|c|}
\hline \multirow[b]{2}{*}{ Treatments } & \multicolumn{4}{|c|}{$2019 / 2020$} & \multicolumn{4}{|c|}{$2020 / 2021$} \\
\hline & $\begin{array}{c}\text { Fruit } \\
\text { weight } \\
\text { (g) }\end{array}$ & $\begin{array}{c}\text { Fruit } \\
\text { length } \\
(\mathrm{cm})\end{array}$ & $\begin{array}{c}\text { Fruit } \\
\text { diameter } \\
(\mathrm{cm})\end{array}$ & $\begin{array}{c}\text { Fruit } \\
\text { firmness } \\
(\mathrm{g} / \mathrm{cm} 2)\end{array}$ & $\begin{array}{c}\text { Fruit } \\
\text { weight } \\
\text { (g) }\end{array}$ & $\begin{array}{c}\text { Fruit } \\
\text { length } \\
(\mathrm{cm})\end{array}$ & $\begin{array}{c}\text { Fruit } \\
\text { diameter } \\
(\mathrm{cm})\end{array}$ & $\begin{array}{c}\text { Fruit } \\
\text { firmness } \\
(\mathrm{g} / \mathrm{cm} 2)\end{array}$ \\
\hline Control & $18.69 \mathrm{f}$ & $4.10 \mathrm{~d}$ & $3.30 \mathrm{~d}$ & $155.00 \mathrm{f}$ & $24.74 \mathrm{~d}$ & $4.87 \mathrm{~d}$ & $3.40 \mathrm{e}$ & $161.87 \mathrm{~h}$ \\
\hline Rhizolex (1g/L) & $21.14 \mathrm{e}$ & $4.17 \mathrm{~cd}$ & $3.46 \mathrm{~cd}$ & $160.00 \mathrm{c}-\mathrm{f}$ & $25.22 \mathrm{~d}$ & $4.90 \mathrm{~cd}$ & $3.61 \mathrm{de}$ & $165.00 \mathrm{gh}$ \\
\hline Chitosan (FS) & 22.97de & $4.57 b c$ & $3.67 \mathrm{abc}$ & $168.57 \mathrm{ab}$ & $26.27 \mathrm{~cd}$ & $5.07 \mathrm{bcd}$ & $3.85 \mathrm{a}-\mathrm{d}$ & $177.33 \mathrm{a}-\mathrm{d}$ \\
\hline Chitosan (RS) & $25.33 \mathrm{~cd}$ & $4.83 \mathrm{ab}$ & $3.83 \mathrm{ab}$ & $168.60 \mathrm{ab}$ & $27.39 b c$ & $4.90 \mathrm{~cd}$ & 3.67 cde & $178.64 \mathrm{ab}$ \\
\hline Chitosan (FS+Rs) & $28.67 \mathrm{a}$ & $5.10 \mathrm{a}$ & $4.00 \mathrm{a}$ & $171.67 \mathrm{a}$ & $30.92 \mathrm{a}$ & $5.53 \mathrm{a}$ & $4.10 \mathrm{a}$ & $179.71 \mathrm{a}$ \\
\hline Methionine (FS) & $24.38 \mathrm{~cd}$ & $4.67 \mathrm{~b}$ & $3.63 \mathrm{bcd}$ & $163.53 \mathrm{~b}-\mathrm{e}$ & $25.65 \mathrm{~cd}$ & $4.90 \mathrm{~cd}$ & $3.86 \mathrm{a}-\mathrm{d}$ & 171.77 ef \\
\hline Methionine (RS) & $25.55 \mathrm{c}$ & $4.86 a b$ & $3.70 \mathrm{abc}$ & $158.33 \mathrm{def}$ & $26.74 \mathrm{~cd}$ & $5.03 \mathrm{bcd}$ & $3.70 \mathrm{bcd}$ & $167.50 \mathrm{fg}$ \\
\hline $\begin{array}{l}\text { Methionine } \\
\text { (FS+RS) }\end{array}$ & $28.36 \mathrm{ab}$ & $4.97 \mathrm{ab}$ & $3.97 \mathrm{ab}$ & $165.13 \mathrm{a}-\mathrm{d}$ & 29.26ab & $5.30 \mathrm{ab}$ & $3.93 \mathrm{abc}$ & $178.40 \mathrm{abc}$ \\
\hline Ascorbic acid (FS) & $24.91 \mathrm{~cd}$ & $4.80 \mathrm{ab}$ & $3.87 \mathrm{ab}$ & $164.93 \mathrm{a}-\mathrm{d}$ & $26.46 \mathrm{~cd}$ & $5.16 \mathrm{bc}$ & $3.73 \mathrm{bcd}$ & $172.37 \mathrm{def}$ \\
\hline Ascorbic acid (RS) & $25.51 \mathrm{c}$ & $4.63 \mathrm{~b}$ & $3.73 \mathrm{abc}$ & 156.67 ef & $26.01 \mathrm{~cd}$ & $5.13 \mathrm{bcd}$ & $3.90 \mathrm{abc}$ & $173.33 \mathrm{cde}$ \\
\hline $\begin{array}{l}\text { Ascorbic acid } \\
(\mathrm{FS}+\mathrm{RS})\end{array}$ & $26.13 b c$ & $4.96 \mathrm{ab}$ & $3.93 \mathrm{ab}$ & $166.67 \mathrm{abc}$ & $29.37 \mathrm{ab}$ & $5.20 \mathrm{~b}$ & $3.97 \mathrm{ab}$ & $173.47 \mathrm{~b}-\mathrm{e}$ \\
\hline
\end{tabular}

Table 7. Effect of some natural compounds i.e. chitosan, methionine and ascorbic acid on chemical fruit quality of strawberry plants cv. Festival during 2019/2020 and 2020/2021 seasons.

\begin{tabular}{|c|c|c|c|c|c|}
\hline Treatments & TSS\% & $\begin{array}{l}\text { Vit.C } \\
\text { (mg/100g f.w) }\end{array}$ & $\begin{array}{l}\text { Acidty } \\
\text { (mg/100g f.w) }\end{array}$ & $\begin{array}{l}\text { Total } \\
\text { sugars\% }\end{array}$ & $\begin{array}{l}\text { Anthocyanin } \\
\text { (mg/100g f.w) }\end{array}$ \\
\hline \multicolumn{6}{|c|}{$2019 / 2020$} \\
\hline Control & $9.90 \mathrm{~d}$ & $51.93 \mathrm{c}$ & $0.93 \mathrm{~d}$ & $5.40 \mathrm{~d}$ & $92.17 \mathrm{c}$ \\
\hline Rhizolex (1g/L) & $10.53 \mathrm{~cd}$ & $53.66 \mathrm{bc}$ & $0.97 \mathrm{~cd}$ & $5.85 \mathrm{~cd}$ & $93.82 \mathrm{c}$ \\
\hline Chitosan (FS) & $10.53 \mathrm{~cd}$ & $56.00 \mathrm{bc}$ & $1.04 \mathrm{bcd}$ & $6.19 \mathrm{bc}$ & $97.29 \mathrm{~b}$ \\
\hline Chitosan (RS) & $10.70 \mathrm{~cd}$ & $56.96 \mathrm{~b}$ & $1.08 \mathrm{abc}$ & $6.22 \mathrm{bc}$ & $98.89 \mathrm{~b}$ \\
\hline Chitosan (FS+Rs) & $11.50 \mathrm{abc}$ & $64.43 \mathrm{a}$ & $1.20 \mathrm{a}$ & $6.62 \mathrm{ab}$ & $102.30 \mathrm{a}$ \\
\hline Methionine (FS) & $10.86 \mathrm{bcd}$ & $66.33 \mathrm{a}$ & $1.13 \mathrm{ab}$ & $6.36 \mathrm{ab}$ & $98.93 \mathrm{~b}$ \\
\hline Methionine (RS) & $11.10 \mathrm{bc}$ & $54.00 \mathrm{bc}$ & $1.09 \mathrm{ab}$ & $6.47 \mathrm{ab}$ & $97.97 \mathrm{~b}$ \\
\hline Methionine (FS+RS) & $11.77 \mathrm{ab}$ & $56.00 \mathrm{bc}$ & $1.15 \mathrm{ab}$ & $6.74 \mathrm{a}$ & $102.37 \mathrm{a}$ \\
\hline Ascorbic acid (FS) & $11.40 \mathrm{abc}$ & $57.50 \mathrm{~b}$ & $1.15 \mathrm{ab}$ & $6.52 \mathrm{ab}$ & $98.63 \mathrm{~b}$ \\
\hline Ascorbic acid (RS) & $11.20 \mathrm{abc}$ & $64.46 \mathrm{a}$ & $1.14 \mathrm{ab}$ & $6.52 \mathrm{ab}$ & $98.80 \mathrm{~b}$ \\
\hline Ascorbic acid (FS+RS) & $12.17 \mathrm{a}$ & $67.70 \mathrm{a}$ & $1.20 \mathrm{a}$ & $6.81 \mathrm{a}$ & $102.85 \mathrm{a}$ \\
\hline \multicolumn{6}{|c|}{$2020 / 2021$} \\
\hline Control & $9.80 \mathrm{~d}$ & $55.33 \mathrm{e}$ & $1.00 \mathrm{~d}$ & $6.52 \mathrm{f}$ & $81.96 \mathrm{e}$ \\
\hline Rhizolex (1g/L) & $10.70 \mathrm{~cd}$ & $57.50 \mathrm{de}$ & $1.03 \mathrm{~cd}$ & 6.64 ef & 83.79 de \\
\hline Chitosa9n (FS) & $11.06 \mathrm{~cd}$ & $59.66 \mathrm{~cd}$ & $1.03 \mathrm{~cd}$ & $6.96 \mathrm{de}$ & $85.00 \mathrm{~cd}$ \\
\hline Chitosan (RS) & $11.50 \mathrm{bc}$ & $60.33 \mathrm{~cd}$ & $1.04 \mathrm{~cd}$ & $7.10 \mathrm{~cd}$ & $87.27 \mathrm{bc}$ \\
\hline Chitosan (FS+Rs) & $11.93 \mathrm{abc}$ & $69.03 \mathrm{ab}$ & $1.16 \mathrm{a}$ & $7.51 \mathrm{ab}$ & $92.45 \mathrm{a}$ \\
\hline Methionine (FS) & $11.33 \mathrm{bc}$ & $61.80 \mathrm{c}$ & $1.05 \mathrm{bcd}$ & $7.18 \mathrm{bcd}$ & $85.79 \mathrm{~cd}$ \\
\hline Methionine (RS) & $11.56 \mathrm{bc}$ & 58.50 cde & $1.13 \mathrm{abc}$ & $7.13 \mathrm{~cd}$ & $89.23 \mathrm{~b}$ \\
\hline Methionine (FS+RS) & $12.41 \mathrm{ab}$ & $69.83 \mathrm{ab}$ & $1.18 \mathrm{a}$ & $7.59 \mathrm{a}$ & $92.63 \mathrm{a}$ \\
\hline Ascorbic acid (FS) & $11.60 \mathrm{bc}$ & $68.53 \mathrm{ab}$ & $1.15 \mathrm{ab}$ & $7.30 \mathrm{abc}$ & $87.29 \mathrm{bc}$ \\
\hline Ascorbic acid (RS) & $11.76 \mathrm{abc}$ & $67.33 \mathrm{~b}$ & $1.15 \mathrm{ab}$ & $7.25 \mathrm{bcd}$ & $88.70 \mathrm{~b}$ \\
\hline Ascorbic acid (FS+RS) & $12.93 \mathrm{a}$ & $72.00 \mathrm{a}$ & $1.19 \mathrm{a}$ & $7.63 \mathrm{a}$ & $92.97 \mathrm{a}$ \\
\hline
\end{tabular}


al. (2010), Shafshak et al. (2011), El-Miniawy et al. (2013) and Shams et al. (2014) in case of using chitosan, Manal et al. (2019) in case of using amino acids and Shadia (2017) in case of using ascorbic acid indicated that applying such forgoing natural compounds reflected positive effect on all measure chemical fruit quality for such tested vegetable crops.

Rhizoctonia root rot disease in strawberry is one of serious soil borne diseases that threatens production. Using of eco-compatible materials may be an alternative to harmful chemicals. The present study had been conducted to evaluate the natural materials root rot caused by Rhizoctonia solani. The present results indicated that applications of chitosan, methionine or ascorbic acid induced resistance against root rot disease and increased strawberry yield. The observed increase in strawberry yield in this study might be due to the reduction of disease incidence, disease severity and promotion of plant growth as a result of using this safety compounds.

It could be suggested that combined applications between foliar spray and root seedling soaking with chitosan, methionine or ascorbic acid might be used commercially as safely and applicable method for controlling strawberry root rot disease and enhancement of growth parameters and increasing fruit yield.

\section{REFERENCES}

Abd El-Mawgoud AMR, Tantawy AS, El-Nemr MA, Sassine YN (2010). Growth and yield responses of strawberry plants to chitosan application. European J. Scientific Research. 39(1): 161-168.

Abdel-Kader MM, El-Mougy NS (2014). Controlling downy and powdery mildews of bill pepper using fungicides alternatives under plastic houses conditions. International Journal of Engineering and Innovative Technology, 4(2): 44-48.

Abd-El-Kareem F, Abd-Alla MA, El-Mohamedy RSR (2002). Induced resistance in potato plants for controlling early blight disease under field condition. Egypt J. Appl. Sci., 17: 51-66.

Abo Sedera FA, Abd El-Latif AA, Bader LAA, Rezk SM (2010). Effect of NPK mineral fertilizer levels and foliar spray with humic and amino acids on yield and quality of strawberry. Eypt. J. of Appl. Sci., 25(4):154-169.

Abo-Hinna MA, Merza TK (2012). Effect of organic manure, tuber weight and ascorbic acid spraying on some vegetative parameters and marketable yield of potato (Solanum tuberosum L.) grown in sandy soil. Agri. Sci. Kufa Magazine: (4) 15-29.
Ahmed HZ, Armanious HAH, Abdel-Moneim ML, Galal AA (2017). Control of root rot and wilt diseases of marjoram by using some mineral compounds and antioxidants. Minia J. of Agric. Res. and Develop., 37(2): 141-156.

Akram NA, Shafiq F, Ashraf M (2017). Ascorbic acid a potential oxidant scavenger and its role in plant development and abiotic stress tolerance. Frontiers in Plant Science, 8: 613.

Anany TG, Ismail AY (2020). Effects of foliar spraying with some Antioxidants on Growth, Dry Seed Yield and Chemical Constituents of Common Bean (Phaseouls vulgaris L.) Plants Grown under Water Stress Levels. J. of Plant Production, Mansoura Univ., Vol 11 (12):1227 - 1238.

AOAC (1990). Official and Tentative Methods of Analysis. Association of Official Analytical Chemists. $15^{\text {th }}$ ed. Washington, D.C, U.S.A. Aberg, B.1961. Nucleceic acids and proteins in plants. Encycl. Plant Physiol., Vol.14, Spriger Verlag, Berlin.

Ashley AB, Judith CH, Li L (1998). Effects of chitin and chitosan on the incidence and severity of Fusarium yellows of celery. Plant Disease, 82 (3), 322-328.

Awad HM (2016). Integrated management of Rhizoctonia root rot disease infecting strawberry in Egypt. Egyptian Journal of Crop Protection,11 (1): 111.

Bell AA, Hubbard JC, Liu L (1998). Effects of chitin and chitosan on the incidence and severity of Fusarium yellows of celery. Plant Disease, 82, 322328.

Benhamou N, Theriault G (1992). Treatment with chitosan enhances resistance of tomato plants to the crown and root rot pathogen Fusarium oxysporum f. sp. radicis-lycopersici. Physiol. Mol. Plant Pathol., 41, 33-52.

Beyer JRWF, Fridovich I (1987). Assaying for superoxide dismutase activity: some large consequences of minor changes in condition. Analytical Biochemistry. 161(2): 559-566.

Bhuiyan NH, Selvaraj G, Wei1 Y, King J (2009). Role of lignification in plant defense. Plant Signaling and Behavior 4:2, 158-159.

Botanga CJ, Bethke G, Chen Z, Gallie DR, Fiehn O, Glazebrook J (2012). Metabolite profiling of Arabidopsis inoculated with Alternaria brassicicola reveals that ascorbate reduces disease severity. Mol Plant Microbe Interact 25(12):1628-1638

Boubakri H (2017). Ascorbic acid in plant growth, Development and Stress Tolerance (pp.255-271) Publisher: Springer International Publishing, Hossain, 
M.A., Munné-Bosch, S, Burritt, D.J., Vivancos, P.D., Fujita, M, Lorence, A. (Eds).

Bradford MM (1976). A rapid and sensitive method for the quantification of microgram quantities of protein utilizing the principles of protein-dye binding. Anal.Biochem., 72, 243-254.

Brown J, Lilleland O (1946). Rapid determination of potassium and sodium in plant material and soil extracts by flame photometric. Proc. Amer. Soc. Hort. Sci., 48: 341- 346.

Dawa KK, Abd El-Nabi HME, Swelam WME (2017). Response of Tomato Plants to Irrigation with Magnetized Water and some Foliar Application Treatments under Drip Irrigation System. J. Plant Production, Mansoura Univ., Vol. 8(11): 1127 - 1133 El-Awadi ME, El-Bassiony AM, Fawzy ZF, ElNemr MA (2011). Response of Snap Bean (Phaseolus vulgaris L) Plants to Nitrogen Fertilizer and Foliar Application with Methionine and Tryptophan. Nature and Science, 2011;9(5) Pages:87-94.

El-Ghaouth A, Arul J, Asselin A, Benhamou N (1992b). Antifungal activity of chitosan on postharvest pathogens: Induction of morphological and cytological alterations in Rhizopus stolonifer. Mycol. Res., 96, 769-779.

El-Ghaouth A, Arul J, Grenier J, Asselin A (1992a). Antifungal activity of chitosan on two postharvest pathogens of strawberry fruits. Phytopathology, 82 (4), 398-402.

El-Miniawy SM, Ragab ME, Youssef SM, Metwally AA (2013). Response of strawberry plants to foliar spraying of chitosan. Research Journal of Agriculture and Biological Sciences, 9(6): 366-372

Errifi A, Touhami AO, Mouden N, El Batnan AM, El Hazzat N, Selmaoui K, Benkirane R, Douira A (2019). Pathogenicity of Rhizoctonia solani towards distinct varieties of cultivated strawberry plants in Morocco. Plant Cell Biotechnology and Molecular Biology, 20(23and24):1086-1099.

Fang XD, Finnegan MP, Barbetti MJ (2013). Wide variation in virulence and genetic diversity of binucleate Rhizoctonia isolates associated with root rot of strawberry in western Australia. PLOS ONE, 8(2): e55877.

Fatma SA, Hanaa AA (2020). Effect of foliar spraywith some growth stimulants on potato plants under different growing media. Plant Archives Volume 20 No. 2, 9244-9252

Gad El-Hak SH, Ahmed AM, Moustafa YMM (2012). Effect of foliar application with two antioxidants and humic acid on growth, yield and yield components of Peas (Pisum sativum L.). J. of
Horticultural Science and Ornamental Plants, 4(3): 318-328.

Gomez KA, Gomez AA (1984). Statistical Procedure for Agricultural Research, 2nd edn. Wiley: new York; 680.

Hasabi V, Askari H, Alavi SM, Zamanizadeh H (2014). Effect of amino acid application on induced resistance against citrus canker disease in lime plants. J. Plant Protec. Res., 54, 144-149.

John MK (1970). Colorimetric determination of phosphorus in soil and plant material with ascorbic acid. Soil Sci., 109: 214-220.

Kadotani N, Akagi A, Takatsuji H, Miwa T, Igarash D (2016). Exogenous proteinogenic amino acids induce systemic resistance in rice. BMC Plant Biology 16:60.

Kim SW, Park JK, Lee CH, Hahn BS, Koo JC (2016). Comparison of the antimicrobial properties of chitosan oligosaccharides (COS) and EDTA against Fusarium fujikuroi causing rice bakanae disease. Current Microbiology, 72(4), 496-502.

Liman Z, Selmi S, Sadok S, El-abed A (2011). Extraction and characterization of chitin and chitosan from crustacean by-products: biological and physicochemical properties. African Journal of Biotechnology, 10(4), 640-647.

Manal AM, Howida AM, Ayat MA (2019). effect of foliar spray with amino acids, citric acid, some calcium compounds and mono-potassium phosphate on productivity, storability and controlling gray mould of strawberry fruits under sandy soil conditions. Zagazig J. Agric. Res., Vol. 46 No. (4).

Matta A, Gentile IA, Ferraris L (1988). Stimulation of B-1,3-glucanase and chitinase by stresses that induce resistance to fusarium wilt in tomato. Phytopath. medit. 27: 45-50.

Mauch F, Hadwiger LA, Boller T (1984). Ethylene: symptom, not signal for the induction of chitinase and b-1,3-glucanase in pea pods by pathogens and elicitors. Plant Physiol., 76, 607-611.

Mohamed MH, Gado E, El-Deeb S, Mostafa HM (2015). Obstruction of signal transduction between faba bean and Rhizoctonia solani during pathogenesis and its impact on root rot disease. International scientific research journal, 1(7): 99-107.

Mohamed MH, Mostafa MH (2021). Comparative studies between treatments of potato tubers slices with three amino acids and treatment with salicylic acid or jasmonic acid on the infection by dry rot (Fusarium solani). Egyptian Journal of Phytopathology, 49(1):129-135.

Mohamed MHM (2015). Effect of some growth stimulants on production and quality of strawberry 
transplants. Annals of Agric. Sci., Moshtohor Vol. 53(4), 693-708.

Mondal MMA, Malek MA, Puteh AB, Ismail MR, Ashrafuzzaman M, Nahe L (2012). Effect of foliar application of chitosan on growth and yield in okra. A.J.C.S., 6: 918-921.

Nelson $N$ (1974). A photometric adaptation of the somogyi methods for determination of glucose. J. Biology. Chem. 195: 19-23.

Nithin KM, Madaiah D, Dinesh KM, Dhananjaya BC, Shivakumar BS, Sahana BJ (2020a). Effect of chitosan application on growth and yield attributes of strawberry (Fragaria $\times$ ananassa Duch.) under naturally ventilated polyhouse. Journal of Pharmacognosy and Phytochemistry . 9(5): 11171120.

Nithin KM, Madaiah D, Shivakumar BS, Kumar MD, Dhananjaya BC (2020b). Influence of Chitosan Foliar Application on Quality and Biochemical Traits of Strawberry (Fragaria $\times$ ananassa Duch.) under Naturally Ventilated Polyhouse. Int.J.Curr.Microbiol.App.Sci (2020) 9(9): 243-250.

Notsu S, Saito N, Kosaki H, Inui H, Hirano S (1994). Stimulation of phenylalanine ammonia-lyase activity and lignification in rice treated with chitin, chitosan and their derivatives. Biosci. Biotechnol. Biochem., 58, 552-553.

Oktay M, Kocacalıskan KF, Sakiroğlu H (1995). Polyphenol oxidase from Amasya apple. Journal of Food Science. 60: 495-499.

Oliveira MDM, Varanda CMR, Felix MRF (2016). Induced resistance during the interaction pathogen $\mathrm{x}$ plant and the use of resistance inducers. Phytochemistry Letters, 15: 152-158.

Parmeter JR, Whitney HS (1970). Taxonomy and nomenclature of the imperfect state. In: Parmeter, J. R. (ed.). Biology and Pathology of Rhizoctonia solani. Univ. of California Press, Berkeley, 225 pp.

Pregl E (1945). Quantitative organic micro analysis. 4 th Ed. J. Chundril, London.

Ramadan ME, El Mesairy MMA (2015). Effect of humic acid and chitosan on growth and yield of okra (Abelmoschus esculentus L.) under saline conditions. Egyptian J. Desert Res., 65, No. 1, 47-60.

Reimers PJ, Leach JE (1991). Race specific resistance to Xanthomonas oryzae pv. oryzae conferred by bacterial blight resistance gene $\mathrm{Xa}-10$ in rice (Oryza sativa) involves accumulation of a ligninlike substance in host tissues. Physiol. Mol. Plant Pathol. 38 (1): 39-55.

Sarosh BR, Sivaramakrishnan S, Shetty HS (2005). Elicitation of defense related enzymes and resistance by L-methionine in pearl millet against downy mildew disease caused by Sclerospora graminicola. Plant Physiol. Biochem. 43 (8): 808-815.

Shadia BDY (2017). Response of potatoes to foliar spray with cobalamin, folic acid and ascorbic acid under North Sinai conditions. Middle East Journal of Agriculture Research. Volume: 06 | Issue : 03 | JulySept. | 2017 Pages:662-672.

Shafshak NS, Eid SM, Abo-Sedera FA, Mohamed MHM (2011). Improving growth and productivity of strawberry via soil addition and foliar application of some safety growth stimulating compounds. Annals Agric. Sci., Moshtohor; 49(2); 153-162.

Shahidi F, Naczk M (1995). Methods of Analysis and Quantification of Phenolic Compounds. Food phenolic: sources, chemistry, effects and applications (pp. 287-293). Technomic Publishind Company, Inc: Lancaster.

Shams AS1, Abo - Sedera FA, Abo El - Yazied A, El-Nagar MM, EL-Badawy MS (2014). Effect of foliar spray with some safety compounds on growth, productivity and quality of some strawberry cultivars. J. Plant Production, Mansoura Univ., Vol. 5 (8): 1419 - 1432

Siddaiah CN, Prasanth KVH, Satyanarayana NR, Mudili V, Gupta VK, Kalagatur NK, Satyavati T, Dai X, Chen J, Mocan A, Singh BP, Srivastava RK (2018). Chitosan nanoparticles having higher degree of acetylation induce resistance against pearl millet downy mildew through nitric oxide generation. Scientific Reports, 8:2485.

Singh BK (1999). Plant amino acids: Biochemistry and Biotechnology. Marcel Dekker.Inc., New York, U.S.A, P.648.

Smith AG, Croft MT, Moulin M, Webb ME (2007). Plants need their vitamins too. Physiol. Metab., 10(3): 266-275.

Sneh B, Henis Y (1972). Production of antifungal substances active against Rhizoctonia solani in chitinamended soil. Phytopathology, 62: 595-600.

Somai-Jemmali LI, Magnin-Robert M, Randoux B, Siah A, Tisserant B, Halama P, Reignault PH, Hamada W (2015). Ascorbic acid controls Mycosphaerella graminicola in bread and durum wheat through direct effect on the pathogen and indirect action via plant defence. Comm. Agric. Appl. Biol. Sci, 80(3): 477-90.

Stamford TCM, .Alcântara SRC, Berger LRR, Stamford NP, Silva MCF, Borges TKS, Laranjeiras D, Campos-Takaki GM (2010). Antimicrobial activity of chitosan against Fusarium oxysporum f. sp. tracheiphilum. Microorganisms in Industry and Environment, pp. 12-15. 


\title{
S. M. Rizk and Maha H. Mohamed., 2021
}

Sumner JB, Somers GF (1947). Chemistry and methods of enzymes, $2^{\text {nd }}$ edition, New York, 209.

Tzeng DD, Tzeng HC, Chen R, Cheng A, Tsai CC, Chen C, Hwang T, Yeh Y, De. Vay JE (1996). The use of MR formulation as a novel and environmentally safe photodynamic fungicide for the control of powdery mildews. Crop Prot. 15 (4): 341-347.

Wang SY, Tzeng DD (1998). Methionine-riboflavin mixtures with surfactants and metal ions reduce powdery mildew infection in strawberry plants. J. Amer. Soc. Hort. Sci., 123(6): 987-991.

\section{الملخص العربى}

استخدام بعض المركبات الطبيعية لتحسين النمو والمحصول وتحمل نباتات الفراولة لمرض عفن الجذور الريزوكتونى

\author{
سيد منصور رزق 'و مها حلمي محمد' \\ ' قسم بحوث البطاطس والخضر خضرية التكاثر - معهد بحوث البساتين - مركز البحوث الزراعية - الجيزة - مصر

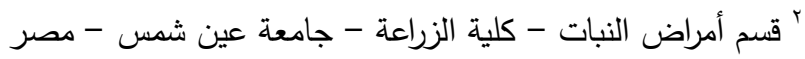

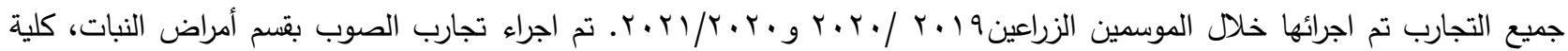

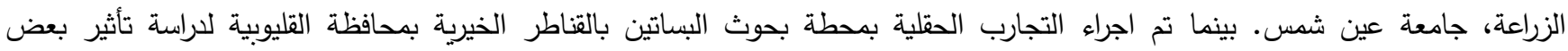

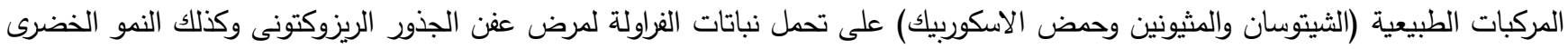
والتركيب الكيماوى للنبات والمحصول الثمرى ومكوناته وكذلك جودة المحصول الناتج من الفراولة صنف فيستيفال مقارنة بنباتات الفراولة المصابة

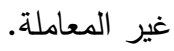

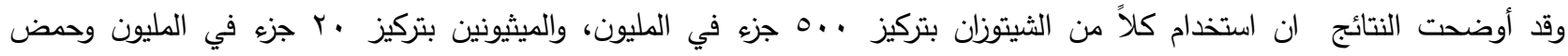

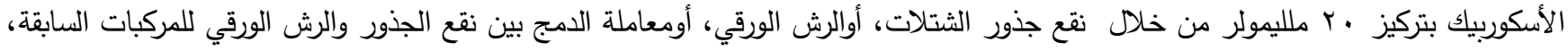
أومعاملة نقع جذور الثتلات في المبيد الفطري ريزوليكس بمعدل اجم/تتر، أدت الى حدوث انخفاض معنوى في حدوث اصابة عفن الجذور

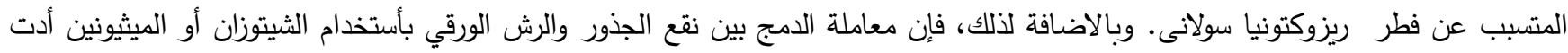

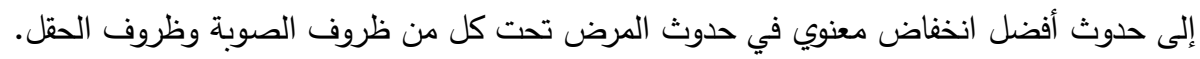

أدت جميع المعاملات باستثناء المبيد الفطري ريزوليكس إلى حدوث زيادة معنوية في الفينولات الكلية ونشاط الإنزيمات المؤكسدة مثل بولي

$$
\text { فينول اكسيديز و سوبر اكسيد ديسيوتيز و الكتاليز خلا موسمي النمو. }
$$

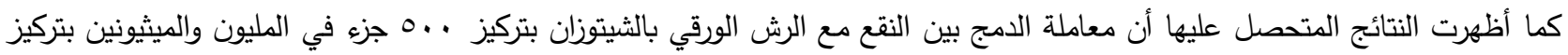

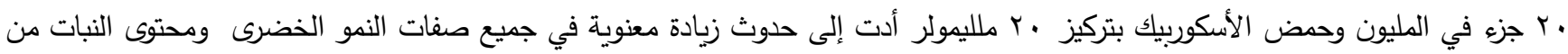

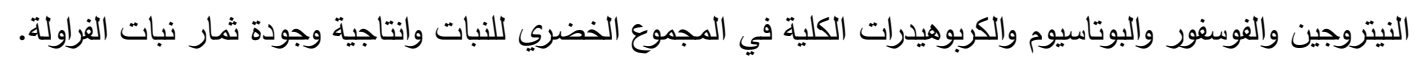

